\title{
Changing Attitudes to Post-execution Punishment 1752-1834
}

Having analysed both the debates that occurred in the period prior to the Murder Act and the sentencing patterns that resulted from that Act, this study will now focus on the complex ways that attitudes towards post-execution punishment developed and changed during the period between 1752 and 1834 . Although the many, largely unintegrated, strands of contemporary discourse that we have access to in the second half of the eighteenth century make it clear that extended debates were occurring, it is difficult at times to identify which of these ideas were most influential. As Devereaux has pointed out in his essay on capital punishment in London during this period, "the substance of "public opinion" as historians are capable of reconstituting it from contemporary sources, often seems both too various in its content and too inconsistently asserted to provide us with any straightforwardly measurable or unidirectional influence on the course of events'. ' However, as parliamentary proceedings began to be at least partially recorded towards the end of the eighteenth century and as systematic recording of all the speeches made in both Houses developed in the early decades of the nineteenth, more detailed analysis of the main points being debated and of the structures of ideas behind them becomes possible.

One thing is immediately clear from these sources. Changing attitudes and policies towards post-execution punishment cannot be explained by any simple unidirectional model. Rather than a pattern of general long-term decline in support for the use of post-execution punishments throughout the period 1752-1834, detailed study reveals a much more

(C) The Author(s) 2017

P. King, Punishing the Criminal Corpse, 1700-1840,

Palgrave Historical Studies in the Criminal Corpse and its Afterlife,

DOI 10.1057/978-1-137-51361-8_4 
complex pattern. In the first four or five decades after 1752 the two main forms of post-execution punishment formalized in the Murder Act, dissection and hanging in chains, were sometimes criticized but rarely fundamentally challenged, and although they did not necessarily fulfill all that had been expected of them, they were seen by most commentators as a functioning and useful part of the criminal justice system. However, attitudes became much more complex at the end of the eighteenth century. As identified in Chap. 3 , in the first 3 years of the nineteenth century the judges suddenly abandoned the use of hanging in chains except in a few highly exceptional circumstances. Dissection therefore became the main post-execution punishment, but, unlike hanging in chains, its popularity did not decline significantly - at least amongst those involved in making penal policy. Indeed proposals advocating the extension of dissection to other categories of offenders continued to be made both inside and outside Parliament until the early 1830s. Although the use of penal dissection was never extended in this way, this particular form of post-execution punishment continued to be seen as an important means of differentiating between different types of capital crime, and penal dissection for murderers alone was still being vigorously defended as such on the very eve of its repeal in 1832. Thus while some forms of post-execution punishment became so unpopular that they were largely abandoned around the turn of the century (burning at the stake after strangling was also ended in the early 1790s), the main form used under the Murder Act-dissection-had a much more complex history and was still regarded by many as a very useful component of the penal system 30 years after hanging in chains had been effectively set aside as unsuitable.

In exploring changing attitudes to post-execution punishment between 1752 and 1834 this chapter will look at a range of issues: at initial discussions about how the Act should be embedded in legal, medical and administrative practice; at how the surgeons responded to their new quasi-penal role; at the various aggravated and post-execution punishments that continued to be put forward as alternatives to, or supplements of, the Murder Act in the mid to late eighteenth century; at the criticisms levelled at hanging in chains, at dissection and at the Murder Act more generally; at the commentators who argued, by contrast, that many parts of the Act were proving useful and functioning well in practice; and at the various suggestions and parliamentary initiatives (such as those of 1786 and 1796) that attempted to extend the use of dissection to the corpses of those found guilty of other crimes apart from murder. It will then focus on the ideas 
and discussions that dominated the final 30 years of the Murder Act period, when the collapse of gibbeting made penal dissection the dominant post-execution punishment. Here it will explore the gradual privatization of penal dissection between 1808 and 1828; the extensive parliamentary debates in relation to three separate legislative initiatives that took place between 1828 and 1832, and which reveal the reluctance of Parliament even at this late stage to end post-execution punishment; the reasons why the penal dissection clause of the Murder Act was finally repealed in 1832, and the final demise of public post-execution punishment through the anti-gibbeting act of 1834 .

\section{The Judges' Initial Discussions About THE Interpretation of the Murder Act}

The 'careless manner in which many Acts of Parliament are drawn up' was the subject of extensive criticism in this period and, like many other eighteenth-century statutes, the Murder Act left much to be desired as a piece of legislation. ${ }^{2}$ Written and passed through both houses of Parliament in a matter of weeks, it was not as complex or convoluted as some eighteenth-century acts, ${ }^{3}$ but its relative brevity brought other problems. It did not, for example, clarify important areas of legislative overlap, such as the relationship between the new act and previous legislation on the punishment of murderers indicted for petty treason. Nor did it make clear precisely how those involved in dissection should perform their new role as 'penal surgeons' or how much discretion they could exercise in doing so. In the years immediately after the act the assize judges, the surgeons and the government's legal officers therefore attempted to clarify exactly how it would work in practice. The twelve judges, who met regularly in London between assize circuits, fairly quickly established how the act should be interpreted by those responsible for sentencing. The surgeons on the other hand had no such central body and no experience in the development of mutual rulings. They therefore continued to interpret and reinterpret their role in diverse ways, often on an individual or regional basis, throughout the Murder Act period.

The assize judges met a couple of months after the Act was passed to consider a number of legal issues raised by it. Some were relatively easily resolved. Accessories before the fact were not deemed to be within the Act, nor could female murderers pleading their belly hope to avoid this new part 
of the death sentence after their babies were born. ${ }^{4}$ After considerable debate and disagreement about whether 'hanging in chains might ever be part of the judgment', the judges decided by a fairly narrow majority that 'the judgment for dissection and anatomizing only should be part of the sentence: and if it should be thought advisable, the judge might afterwards direct the hanging in chains by special order to the sheriff'. It was also agreed by 'the greater part of the Judges', that 'the judgment for dissecting and anatomizing ... ought to be pronounced in cases of petty treason' but 'more as to men in toto but in women only in respect of the time of execution, because they are to be burnt'. The judges were unanimous, however, that with the above exception 'the sentence directed by the Act extends to women as well as men'. Following these initial debates in May 1752, the judges do not appear to have discussed the Murder Act again until 1760 when 'Some doubts having arisen in the House of Lords' about how far the Murder Act 'ought to be put in execution in the case of Earl Ferrers now under sentence of death', they decided that a peer should receive the same judgment as a commoner under the Murder Act. In addition, this case (which, as we will see, also caused problems of interpretation for the surgeons) produced another ruling: that reprieves under the Murder Act could be granted 'as often as the King shall think fit'. ${ }^{6}$

\section{The Surgeons' Interpretations of the Murder} ACT

The sheriff's role as the official responsible for organizing the gibbeting of offenders sentenced to hanging in chains did not change after the Murder Act, and if dissection was the sentence chosen by the court the same official was merely ordered to convey the body of the executed murderer 'to the Hall of the Surgeons' Company or such other place as the said Company shall appoint'. 7 The major new actors introduced into the penal process by the Murder Act were therefore the surgeons themselves, but it left their role almost completely undefined. The Act simply stated that 'the body so delivered ... shall be dissected and anatomized by the said surgeons, or such persons as they shall appoint for that purpose' and that a parallel procedure should also occur in the provinces. ${ }^{8}$ The Act did not therefore stipulate that anatomization/dissection had to be performed in public. Nor did it define what those two processes involved, or lay down any particular procedure that should be followed, leaving all the key issues-such as 
whether the surgeons could chose to make only a token incision-completely unaddressed by the formal law. Beyond the preamble's vague statement that the Act was designed to add 'some further terror and peculiar mark of infamy' 9 to the punishment of death, nothing was stipulated.

Richardson suggested that 'the surgeons were regarded by law as agents of the crown, and protected as such', but while it is true that the Murder Act did try to protect the surgeons from losing the criminal corpses allocated to them, by making it a transportable offence to rescue those corpses, the Act set up no mechanism for controlling the surgeons, for ensuring that a minimum level of dissection took place, or for disciplining them if they failed to perform as required. ${ }^{10}$ If they were agents of the crown they were agents given immense freedom of operation. Sawday's description of the post-execution process, or 'penal dissection' as he called it, suggests that the Murder Act 'delineated the full, ferocious, outlines of the practice of "penal anatomy". ." In reality, however, the Act failed to delineate anything. Elizabeth Hurren's excellent study of the Murder Act period, Dissecting the Criminal Corpse, which offers a detailed analysis of the diverse and innovative ways in which the surgeons fulfilled this role, makes it clear that the Act placed 'a high degree of discretionary justice' in their hands. ${ }^{12}$ The journey from gallows to grave, which the surgeons were responsible for whenever a dissection sentence was passed, was shaped by many complex and regionally variable factors. As Hurren points out, this 'post-execution spectacle did not always have an undeviating medical logic', nor was 'the legal narrative of the punishment drama' staged by the surgeons 'necessarily linear'. ${ }^{13}$ What is clear, however, is that the surgeons oversaw a 'spectacular post-execution encore' in which large crowds could be involved at various stages. Many thousands, for example, sometimes walked past the corpse when it was exposed to public view, both in London and at many of the diverse types of venue used by the provincial surgeons. ${ }^{14}$ These audiences often witnessed a variety of post-execution rites drawn out over several days that involved, Hurren argues, a strong element of 'immersive theatre'. ${ }^{15}$ Within these rituals, however, she has identified two distinct stages. After 1752 the surgeons redefined the general legal term 'dissected and anatomized' as two separate punishment procedures. In the process they not only reversed the order-putting anatomization first-but also informally created what Hurren terms 'the clandestine side of the Murder Act'. ${ }^{16}$ The first procedure, anatomization, involved determining whether medical death had actually occurred, and then acting 
to ensure that it had. Since a considerable proportion of criminal bodies were not medically dead on arrival at the surgical venue this made the surgeons, Hurren argues persuasively, not one step removed from the penal sentence but actually part and parcel of the execution itself. Unlike anatomization, which was primarily about getting the body to become a corpse, ${ }^{17}$ the second procedure, dissection, represented the core of the post-execution punishment to which that corpse was subjected. The degree of post-mortem harm inflicted varied tremendously, but in many cases it involved cutting the body 'on the extremities to the extremities' and a degree of dismemberment that 'despoiled' the murderer as a human being. ${ }^{18}$ Since 'over two-thirds of the human material was generally disposed of' this process resembled 'a macabre showcase ... a public drama of the unsavoury', which Hurren explores in detail in her book. ${ }^{19}$

The degree to which the various surgeons who found themselves placed at the centre of this dissection drama consciously took on the role of 'penal surgeons' remains unclear. A fairly large proportion of surgeons performed only one or two criminal dissections in their professional lifetimes-especially if they lived in one of the smaller provincial counties. Many of them therefore approached the task with relatively little experience to draw on. Did they see themselves as penal surgeons? The records suggest that individual surgeons reacted in very different ways and that it is possible to find some who completely spurned the role, and others who enthusiastically embraced it. At one extreme the courts were occasionally forced to hang offenders in chains because the local surgeons refused to dissect or anatomize their corpses. On other occasions the surgeons accepted the corpse but then made little or no attempt to make incisions upon it. At the other extreme there were those who fully embraced the role of penal surgeon, seeing themselves as responsible for the 'completion of the sentence'. ${ }^{20}$ When the case involved a relatively low profile provincial murderer the surgeons may often have been free to take a relatively minimalist approach to the dissection process, if they chose to do so. However, when some of the London surgeons involved in the dissection of Earl Ferrers suggested an approach that would minimalize the post-mortem harm done to his corpse their decisions were heavily scrutinized in the press and subjected to considerable criticism. This forced them to seek advice from the government's leading lawyer, a process that created sources that give us important insights into the administration's own interpretation of this aspect of the Murder Act. 
In May 1760 it was reported in the newspapers that the prospect of having to dissect a member of the aristocracy had created 'a dispute among the surgeons about what parts, and how much or how little shall be anatomized; some say a scratch is sufficient others affirm that only the bowels are to be taken out and then returned'. The reports then went on to note that 'this morning a court of the assistants of the Surgeons' Company will meet to consider the letter of the law. ${ }^{21}$ Under pressure both from some of the popular press, who demanded that Ferrers be treated like all other convicted murderers, and from other public figures who felt that a full-scale dissection was not warranted, ${ }^{22}$ the surgeons court immediately sought the opinion of the Attorney General. While warning that 'they must be careful not to evade the Act', he largely handed the decision about the degree to which they were obliged to carry out a dissection back to them, saying that he thought that they would be better judges than him on the issue and adding that 'he did not think that anyone would ever question whether the body had been sufficiently dissected. They could dissect the whole or any part of the body as they thought fit'. ${ }^{23}$ By reacting in this way and pointing out in addition that the surgeons 'were not directed to make the dissection in public or to exhibit the body', ${ }^{24}$ the government's key legal representative effectively gave the surgeons carte blanche. In the Ferrers' case the London surgeons eventually compromised, anatomizing the noble Lord but not dissecting his corpse to the extremities and then permitting the public to view it. ${ }^{25}$

Class was not, however, the only criteria that might lead the surgeons to minimalize their penal role. In the 1780s, faced by what many considered to be the wrongful murder conviction and hanging of an army surgeon's son in Northampton, the local surgeons simply handed the corpse straight back to the family to bury as they wished, without cutting it at all. ${ }^{26}$ Other surgeons made only token incisions, usually because they had sympathy with the executed man. In 1799 a Flemish-born 'Man of property' who had been found guilty of murder for neglectfully causing the death of an 8 -year-old servant under circumstances that would have normally led only to a manslaughter conviction, was only subjected to 'a few incisions in order to fulfil the sentence' by the Welsh surgeons to whom his body had been delivered by the court. His near intact corpse was then 'given to his friends who had it put in a decent coffin and conveyed to his wife and family'. ${ }^{27}$ Four years earlier, after William White had been hanged for murder at Bath, the surgeons followed a similar course, only making a few incisions before handing the body over to relatives for burial. ${ }^{28}$ 
Some surgeons also refused to dissect the criminal corpses sent to them by the courts for medical reasons. In 1762 the Surgeons of York refused to take such a corpse 'on account of its being full of ulcers'. ${ }^{29}$ On several other occasions-in 1759, 1767, 1772 and 1797 for example-the reasons for the surgeon's refusal is less clear, the sheriffs records simply noting that the corpse was gibbeted because the surgeon was not willing to dissect it. ${ }^{30}$ Throughout the second half of the eighteenth century, therefore, it is possible to find at least a few surgeons who refused to take on the role of 'penal surgeon' at all, and others who chose to minimize the impact they made on the criminal's corpse when being required to play that role. Moreover, although it is unclear whether they knew about it or not, the Attorney General's response in 1760 suggests that they were quite within their rights to do so.

However, this should not be taken to indicate that this minimalist approach was the norm. Systematic records do not exist but it is probable that the great majority of surgeons in all but the most remote regions willingly took on the task both of anatomizing the criminal corpses sent to them and of subjecting them to a substantial process of dissection. The surgeons' desperate need of cadavers for teaching and anatomical investigation was much publicized and many surgeons also stood to make financial and reputational gains from being involved in public dissections. ${ }^{31}$ William Hey, for example, netted profits for his hospital of over $£ 80$ from one dissection process alone-the equivalent of two-years wages for a labourer. ${ }^{32}$ A considerable proportion of these surgeons may have performed dissections despite the fact that they were troubled by the harshness of the Murder Act and the dehumanizing processes it prescribed. ${ }^{33}$ However, there were undoubtedly others who embraced the role of penal surgeon wholeheartedly.

In 1759, for example, 'one of the Masters of Anatomy for that year' gave two powerful speeches as part of his lectures at Surgeons' Hall over the body of the murderer Richard Lamb. His first lecture began by praising the government for passing the Murder Act seven years before and thereby adding this additional punishment, 'it being well known in how great horror dissection was held by almost all mankind' and especially by the lower class who 'shuddered at the thoughts of being made an otomy'. 34 After acknowledging that 'curiosity more than improvement' had 'drawn the greater part of this audience together', he suggested that they would still benefit considerably from coming. 'Happy it would be', he announced, 'if this publick occasion, this sight of death, may prove a monitor to every 
individual here, and by them be repeated to their acquaintance (especially those prone to wrath) always to have in their eye this table whenever they find themselves urged by the passions of malice and revenge ... Let therefore the anatomical table in the Surgeons' Theatre be a preacher to all, and should their passions run high ... may this dread table present itself to their view and restrain their arm, raised to deprive a fellow creature of life'. Two days later, after the dissection and desecration of Lamb's corpse he returned to this theme. 'These lectures were not intended solely for anatomical benefit', he reminded his audience, but 'to strike greater terror into the minds of men, not by inhuman tortures on the living subject, as in other countries, but by denying the murderer the privilege of having his bones rest peacefully in the ground ... I think few who now look upon that miserable, mangled object before us, can ever forget it. It is for this purpose that our doors are opened to the publick, that all may see the exemplary punishment of a murderer and that it may be impressed on their minds, and be a warning to others to avoid their fate'. ${ }^{35}$

Clearly at least some surgeons revelled in the role of 'penal surgeon' and in London in particular their Company also used the bones of a small minority of criminal corpses to add a further level of post-execution punishment, which was effectively their own local form of gibbeting. On these occasions the surgeons not only dissected to the extremities but also sent the bones to be reconstructed as a skeleton and then hung it (with a name plate attached) in one of the niches created for public display around the dissection room at Surgeons Hall. This not only meant that a public reminder of their names and crimes remained for many years, but also that, unlike others who were dissected, they had no chance whatever of having what was left of their remains decently interred. ${ }^{36}$ The selection of corpses/skeletons for this further punishment seems to have been largely done by the surgeons themselves, although they were no doubt influenced by the views of others, and were very occasionally specifically requested to consider this option by the trial judge. ${ }^{37}$ They usually resorted to this procedure when the murder committed by the executed offender was particularly heinous and/or notorious. In 1767, for example, Elizabeth Brownrigg, who had gradually whipped her apprentice to death, had her skeleton reconstructed and displayed 'in the niche opposite the front door in the Surgeons' Theatre ... in order to perpetuate the heinousness of her cruelty in the minds of the spectators'. ${ }^{38}$ Four years later the surgeons gave the same treatment to another highly notorious offender, Levi Weil, the leader of a violent Jewish gang who had murdered a servant during a 
robbery. Levi was a trained physician and had a degree in physic from Leiden University, but this did not save him from the ultimate destination for the dissected-his own niche at Surgeons' Hall. ${ }^{39}$ The particularly cruel and violent robberies and murder committed by his gang had been widely reported in the newspapers and had led to a major wave of anti-Jewish feeling, and he was therefore a prime candidate for this strange combination of dissection and long-term public display. ${ }^{40}$ His wife had pleaded with the surgeons after his dissection 'earnestly begging the body of her husband for internment' but the decision had already been made to hang his skeleton 'in Surgeons Hall'. ${ }^{41}$

The small sub-group of dissected offenders selected for this punishment included a considerable range of different types of convicts. Thomas Wilford, a one-armed workhouse inmate who had murdered his wife (also a workhouse inmate) three days after they were married, appears to have had his skeleton put in a niche simply because he was the first convict to be dissected under the Murder Act. ${ }^{42}$ However, celebrity status was clearly a particularly important criterion. A few years before the Act James Maclean was given a niche mainly on the basis of his widespread reputation as a well-dressed and well-connected 'gentleman highwayman', while the selection of the violent highway robber James Field was almost certainly due to his reputation as a prize fighter. ${ }^{43}$ The selection criteria remain obscure, but it is possible that in choosing which offenders to display as skeletons the surgeons may sometimes have given preference to those who were not only notorious murderers but were also members of ethnic minorities. In 1786 the black offender, John Hogan, who had murdered a young servant girl because she would not 'submit to his unchaste desires'44 was also given a niche in Surgeons' Hall. The selection process was not always given extensive coverage in the newspapers but if any contemporaries were initially unaware that Hogan had been a given a niche they would have been in no doubt after reading the reports a year later concerning the huge crowds that had gathered to see the body of Henrietta Radbourn, who had been dissected at Surgeons' Hall after being executed for murdering her mistress. 'A vast concourse of people were in the gallery around the amphitheatre' the Morning Chronicle reported, when 'one of the skeletons, which was placed in a niche, fell down, and caused a consternation better conceived than described. The women fainted, and the men were frightened.' Hogan's posthumous revenge was short lived. 'In a short time the panic subsided, the place was soon cleared and the skeleton replaced', the newspaper reported, 'which was that of the black who was 
executed some time ago for the murder of the maid-servant'. ${ }^{45}$ We should not necessarily assume that the surgeons were prejudiced against, rather than simply interested in, the skeletons of ethnic minorities but it is possible that the surgeons were particularly keen, for what they would have seen as scientific reasons, to preserve the skeletons of dissected offenders whom they conceived to be members of specific racial groups. ${ }^{46}$

Overall, however, even though the criteria they used are difficult to unravel, what is clear is that the surgeons, both in London and to a lesser extent in the Provinces, ${ }^{47}$ had the discretionary right to subject the corpses of particular offenders to a potent combination of post-execution punishments-dissection followed by skeletal display-which combined public dismemberment and many of the elements of gibbeting, that is, long term exposure to public gaze and the denial of decent interment. Since, at the other extreme, the surgeons could also show mercy by effectively enabling selected corpses to avoid all, or almost all, the elements of public dissection, these medical men played an extremely important role in deciding what actual treatment each criminal corpse received, even though these powers were in no way spelt out by the Murder Act itself. Dissection and discretion went hand in hand and the surgeons were given huge power to decide the fate of each of the criminal corpses given to them, making them yet another potent example of the way justice was remade from the margins in the eighteenth and early-nineteenth centuries. ${ }^{48}$

\section{Initial Reactions to the Murder Act in Operation, 1752-1759}

Broadly speaking the immediate reaction of contemporaries to the 1752 Murder Act seems to have been a positive one. The widespread publication of the main clauses of the Act, which was a feature of both the London and the provincial newspapers in the early spring of 1752, was frequently accompanied by remarks suggesting that the Act was welcomed and was expected to have positive results. ${ }^{49}$ In early July the Ordinary of Newgate, John Taylor, while admitting that the Act could not be expected to put an end to murder altogether, was praising the legislature for being 'willing to do all in their power' to curb it, by denying murderers a Christian burial and subjecting them to dissection, this being 'the utmost stretch of rigour that humanity can allow'. ${ }^{50}$ A newspaper article published a few days earlier also lauded 'the several acts passed last session against murder and 
robbery', but went on to suggest that, 'like all human institutions, they were not without defects'. ${ }^{1}$

By the second half of 1752 the Murder Act was getting a much more mixed reception. Faced by two convictions and executions for murder in early September, John Taylor was forced to conclude that 'despite the late endeavours of the legislative power', this 'fresh instance ... so soon after so wholesome a Law enacted, seems to shew that it yet wants to be impressed on the minds of men'. ${ }^{52}$ Other commentators, who were not hindered (as Taylor was) by being government employees, were much less deferential in their criticisms. The author of A Warning Piece Against the Crime of Murder, for example, made the cogent point that even though the Murder Act had introduced a more severe punishment 'than was ever practis'd before by the English laws', the Act would not prevent murder because the perpetrators usually believed they could keep their crimes secret. ${ }^{53}$ By 1754 there had clearly been 'many debates about the expediency of dissection' and the King himself was asking the legislature to 'try to find out some new laws for putting a stop to robberies and murders' ${ }^{54}$ Romaine's pamphlet on the frequency of murders, published that year, was also far from positive about the Act. 'The legislature has been lately alarmed at their prodigious increase', he wrote, 'and has been trying to find out some effectual remedy: but what has been hitherto attempted has not met with the desired success ... murders are still as common as ever ... The heart is the cause of all, and no act of parliament can touch the heart'. ${ }^{55}$ In the following year the Gentleman's Magazine openly criticized 'the late laws' for failing to have an impact on 'the frequency of murder', and the London Magazine carried two articles criticizing hanging in chains and pointing out that robberies were being committed 'almost under the very gallows where some former highwayman hangs in chains'. 56

As the 1750s came to a close there was still optimism in some quarters. The 1759 London surgeon's speech already quoted in detail argued that the Murder Act 'still promises success', basing this view on the fact that only two offenders had been executed for murder 'in this large and populous city ... for upwards of two years' ${ }^{57}$ Others were more sanguine, however. After reporting an attempt to remove a gibbeted body from a Salford gallows in 1759 the local newspaper observed that murder had clearly 'puzzled the legislative power' since Parliament had failed 'either to put a stop to it, or to find out a punishment adequate to the offence'. ${ }^{58}$ In the early years of its operation, the Murder Act therefore gained both a level of acceptance-there were no calls for its repeal and it was usually 
acknowledged to have been well-intentioned-and generated a considerable degree of pessimism about its likely impact and effectiveness. Between the late 1750s and the penal crisis of the mid-1780s this mixture-considerable criticism combined with broad acceptance-continued to dominate discussions of post-execution punishment but these themes were intermingled with two other related, but essentially opposite, strands of opinion-those that wanted to see the development of alternative punishments and those that wanted to see the Murder Act extended to a number of other crimes.

\section{Acceptance, Debate and Criticism: The Murder Act in Operation Mid-1750s to THE Mid-1780s}

As we saw in Chap. 3, the period between the 1750s and the capital punishment crisis of the mid/late 1780s witnessed both the establishment of post-execution punishment as part of the normal penal response to murder, and the continued use of hanging in chains against some major property offenders and Admiralty Court convicts. Yet although these four decades witnessed the establishment of dissection and hanging in chains as accepted and taken-for-granted parts of the English criminal justice system, the same period also saw the development of broader critiques of capital punishment, which had important long-term implications for the role of post-execution punishment. In the two decades leading up to the mid-1780s English authors such as Eden and Blackstone, Dawes and Dagge, Howard and Hanway ${ }^{59}$ had begun to question both the usefulness and the morality of capital punishment and to suggest various alternatives and, although those who wanted to reform the capital code made no significant progress until the nineteenth century, these writings gradually began to have an increasing impact.

In creating this critique these English authors called on the influential ideas already published by continental writers such as Beccaria and Montesquieu. ${ }^{60}$ By calling for moderation and denouncing punishments based on terror or extreme intimidation; by arguing that the long-term deprivation of an offender's liberty had a greater impact than the terrible but momentary spectacle of death; and by stressing that certainty of punishment was much more effective than severity, ${ }^{61}$ these writers began to undermine the foundations of the capital punishment system on which the extensive use of post-execution punishment in Britain was based. 
Beccaria's writings also contained brief critical comments on aggravated and post-execution punishments and on the punishment of murder. The degree to which the poor might be 'deterred from violating the laws by the gibbet or the wheel' was very limited, he suggested. ${ }^{62}$ 'In proportion as punishments become more cruel, the minds of men ... grow hardened and insensible; and ... in the space of an hundred years the wheel terrifies no more than formerly the prison'. ${ }^{63}$ Moreover 'the impossibility of establishing an exact proportion between the crime and punishment' raised other problems 'for though ingenious cruelty hath greatly multiplied the variety of torments, yet the human frame can suffer only to a certain degree $\ldots$ be the enormity of the crime ever so great'. ${ }^{64}$ Unlike many writers Beccaria also extended his critique of capital punishment to include its use in cases involving murder. 'Is it not absurd', he argued, 'that the laws, which detest and punish homicide, should, in order to prevent murder, publicly commit murder themselves? 65

Continental writers such as Beccaria were primarily concerned with attacking the capital punishment system as a whole, rather than focusing on its aggravated and post-execution forms, and since dissection was rarely used as a formal punishment on the continent they did not discuss it. Some English writers also gave these issues only passing attention. Dawes, for example, confined himself mainly to pointing out that punishment was made effectual more 'by its certainty than severity, and makes a stronger impression on the mind, than if attended by torment or cruelty'. ${ }^{66}$ However, writers such as Eden and Blackstone did include some discussion of post-execution punishment, as we will see, and a range of different newspaper reports, magazine articles and other commentaries also included aggravated and post-execution punishments in their discussions of the criminal code and their suggestions about the need to reform it. Many of these writers aimed their comments and criticisms mainly at particular forms of post-execution punishment or suggested alternatives to, or extensions of, the sanctions imposed on the criminal corpse by the Murder Act. However, two of the core arguments that can be found in the works published between the 1750s and the mid-1780s involved more general and fundamental critiques of the Murder Act and the assumptions on which it was based.

The most direct of these two critiques, and the only one that was based on empirical evidence about the impact of the Murder Act, was published by the Recorder of London in 1772. This compared the number of murder convictions in London and Middlesex in the 20 years before the Murder 
Act $(80)$ with the number of murderers convicted between 1752 and 1772 (75), and concluded that in all that period there are only five difference, which I think may serve to show that our laws against murderers are not severe enough'. ${ }^{67}$ Dissection was not working as a penal sanction, he argued; 'The murderer is anatomized, but very few of them mind that, as it is attended with no pain to them. ${ }^{68}$ The Recorder also suggested that 'the murders committed since the Act took place were attended with more barbarity than any I can find before'. ${ }^{69}$ However, neither of these arguments was unproblematic. His theory that a qualitative change had occurred after 1752 in the nature of the murders being committed was unsubstantiated and highly subjective. His calculations that the Act had had no effect on murder conviction levels failed to allow for the fact that the London population increased rapidly in this period which meant that, as Shoemaker's recent work has confirmed, murder rates were actually declining. $^{70}$

The Recorder also drew on the other general critique of the Murder Act that can be found in the post-1752 literature. The law against murder was not severe enough, he argued, because 'the man who robs me of a few pence to keep his family from starving is liable to the same punishment as the villain who breaks open my house in the night and murders me in my bed'. ${ }^{71}$ This theme was also taken up by several other commentators in the early 1770s as part of a more general wave of criticism of the English criminal law. In November 1770 Sir William Meredith, during his speech in the House of Commons calling for a parliamentary enquiry into the capital code, pointed out 'that a man who had privately picked a pocket of a handkerchief worth thirteen pence, is punished with the same severity as if he had murdered a whole family of benefactors'. ${ }^{72}$ A London Magazine article published in the same year similarly argued that 'the greater part of mankind' could never accept that 'to pick the pocket and to pierce the heart, is equally criminal' or that both should therefore be subject to the death sentence' ${ }^{73}$

This view that under the existing capital code the degree of punishment was 'by no means proportionable ... to the degree of guilt" ${ }^{74}$ echoed similar arguments made in the run up to the passing of the Murder Act (Chap. 2) and in doing so they implicitly criticized much of the logic and purpose of that Act. These comments implied, or in some cases directly stated, that the compulsory addition of a post-execution punishment to the sentence passed on all convicted murderers had had a negligible effect and could not be regarded as creating a meaningful differentiation in the depth 
of punishment imposed. In arguing that the murderer and the pickpocket were "doomed to the same punishment" ${ }^{, 75}$ these critics effectively wrote off (or perhaps deliberately ignored) both the idea that dissection or hanging in chains could be seen as an extra layer of punishment, and the underlying logic that partly lay behind their imposition, that is, that they might be an effective deterrent.

This dismissal of the Murder Act by some of the more radical early criminal law reformers was not representative of broader opinion, however. As we will see, many judges and penal commentators were still arguing that the post-execution sanctions mobilized by the Murder Act did create differentiation in punishment right up to the early 1830s. These eighteenth century reformers seem to have been mainly arguing against the effectiveness of post-execution punishment in order to strengthen their core argument-which was a critique of capital punishment per se, rather than a direct attack on the punishments imposed on the criminal corpse. In particular, several of them wanted to use the argument that only murder should be punished with death ${ }^{76}$ as a means of introducing a major reform in the ways the criminal justice system punished non-violent offenders. If hanging was largely confined to murder, Meredith argued, 'capital punishment, as it would be less common, would operate more forcibly in terrorem and consequently more effectively answer its end'. ${ }^{77}$ This theme can also be found in several publications produced in the early and mid-1780s. 'It ought ... to be the study of the legislature, not to impose death as a punishment except for murder', Dawes wrote in 1782, quoting both Beccaria and the Old Testament in support of his views, and a few years later Lord Gordon argued controversially that that the word of God did not allow the death sentence for theft and therefore that 'no man ought to suffer death without he spilt blood'. ${ }^{78}$ It would take the reformers another half century to achieve this change and it would also only be at that point that post-mortem punishment under the Murder Act was finally done away with. However, it is clear that as early as 1770 there were already some commentators who did not see either of the two post-execution punishments introduced by the Murder Act as capable of producing the differentiation between punishments that they felt was required, and this theme came to the fore once again during the capital punishment crisis of the mid-/late 1780s, 'Cruel punishments are inflicted upon crimes with which they bear not the least proportion' The Times argued in 1786, before publishing several other more specific articles abhorring the equal punishment given to poor thieves 'pinched by want ... 
and cruel murderers'; to sheep thieves and those committing 'shocking ... robbery and murder'; and to 'the poor thief who steals a coat and the hardened villain who attacks you by night, turns you naked to the storm, mutilates your limbs and deprives you of life itself ${ }^{79}$ However, this critique of the lack of differentiation in the use of capital punishment, with its implication that the post-execution punishments introduced by the Murder Act had failed to remedy this, was by no means dominant. Several commentators, including the influential penal reformer William Eden, continued to analyse, and often to praise, the role of either dissection or hanging in chains as separate sentencing options.

Eden's important book Principles of the Penal Law published in 1772 was broadly, if slightly reluctantly, positive about the role of the surgeon's in post-execution punishment. 'To the dissection of criminals', he wrote, 'it is impossible to offer any solid objection'. However, his views on hanging in chains were very different. 'We leave each other to rot, like scarecrows in the hedges', he observed, 'and our gibbets are crowded with human carcasses. May it not be doubted, whether a forced familiarity with such objects can have any other effect, than to blunt the sentiments ... of the people? ${ }^{80}$ Five years later a generally positive evaluation of the development of post-execution punishment also singled out dissection as the best current option. 'The chief end of punishment is example', it argued.

Hence legislators frequently change the mode of punishment. When one becomes familiar, and has lost its terror, another is adopted. Hanging in chains has had a superior effect when the simple execution at Tyburn has made no impression, and when the horror of being exposed in chains has lost its force, the change from a gibbet to Surgeons' Hall has created new terrors in the most hardened villains. ${ }^{81}$

Occasionally the newspapers carried reports that suggested that these 'new terrors' could have a real impact, at least on the minority of potential offenders who attended dissections. In 1785 one offender was reported to have been 'more shocked at the idea of being dissected at Surgeons' Hall than with death itself', because 'the horrid spectacles he had seen there of several murderers ... made a deep impression upon his mind' ${ }^{82}$ In one sense, this was precisely what the surgeon who spoke of the deterrent value of public dissections in 1759 had hoped would be the effect on the audience, except, of course, that despite the fear this spectacle engendered the offender still went on to commit murder. 
Other newspaper reports and magazine articles tended to be less positive about dissection. 'The murderer will indeed have some marks of disgrace put upon his body after it is dead' one newspaper observed in 1786 'but the person, in fact, suffers no more for this enormous crime than the other who has committed a trifling offence'. ${ }^{83}$ Other writers went further suggesting that public dissection was having a negative effect. 'The exposing the bodies of murderers', they suggested, 'has not appeared to have the salutary effect expected by the Act of Parliament; but from being frequently repeated tends to harden the minds of the vulgar and familiarize them with spectacles of horror' ${ }^{84}$ - a sentiment echoed by the Lady's Magazine in 1782, which suggested that viewing such shocking scenes 'hardens the human mind' ${ }^{85}$ Hanging in chains also had its critics. Eden was not the only commentator to reflect negatively on its role. Blackstone pointed out that it was 'quite contrary to the express comments of Mosaic law'86 and the London Magazine paralleled the Recorder of London's comments on dissection by arguing that 'hardened criminals ... think that, because there is no corporal sufferance in it ... being gibbeted ... makes no part of the punishment'. ${ }^{87}$ Other commentators disagreed, arguing that 'the stoutest of villains have trembled at the imaginary evil of hanging in chains, ${ }^{88}$ and gibbeting was sometimes specifically recommended as more effective than dissection. In 1773, for example, the dissection of a Yorkshire murderer led the local paper to comment that 'it is a pity he was not gibbeted ... as the remembrance would have existed these twenty years, whereas now, in a month, it will be forgotten' ${ }^{89}$ Penal commentators therefore had very mixed feelings about these two post-execution punishments in this period. Some favoured dissection, others preferred hanging in chains while a considerable number remained ambivalent about both options whilst still broadly accepting their introduction under the Murder Act. Another relatively small group suggested various alternative aggravated or post-execution punishments, implying by doing so that the sanctions introduced by that Act were inadequate.

\section{Suggestions for Alternative Aggravated and Post-execution Punishments 1752-1786}

Although there were still occasional calls for 'a more terrifying punishment' than the gallows, ${ }^{90}$ few of the aggravated execution options proposed and debated in years before the Murder Act were given serious consideration in 
the second half of the eighteenth century. Three were at least briefly mentioned. One newspaper article got close to recommending Lex Talionis in 1770. 'The late horrid frequency of murders would tempt one to wish for a revival of the ancient Lex Talionis', it suggested, 'let him who shoots another be shot; who strangles his fellow creature be strangled, ${ }^{91}$ and a year earlier Blackstone mentioned in passing the lack of 'an exemplary punishment' for parricide ${ }^{92}$ an issue that was also debated in the run up to the 1752 Act. In the mid-1780s William Paley, in searching for a way to 'augment the horror of punishment without offending ... public sensibility' mentioned a recent proposal which involved privately 'casting murderers into a den of wild beasts'. ${ }^{93}$ In general, however, the other forms of aggravated execution-breaking on the wheel, gibbeting alive or burning alive and so forth-that were quite frequently advocated before 1752 (Chap. 2) found no place in these later debates. In 1762 the Tyburn crowd did create its own brief form of post-execution punishment by stoning the bodies of two women who had just been executed for murdering their apprentice, whilst they were still hanging on the gallows. ${ }^{94}$ However, the only major post-execution sanction proposed in these years centred on the method of burying the offender's corpse. In 1775 Hanway advocated the burial of the hanged in a special, well-marked and 'strongly walled in ... malefactors burial place' by 'a road near the entrance to a city, such as Tyburn', which he believed 'could not fail of making some impression' on the minds of likely offenders. ${ }^{95}$ Ten years later The Times despite pointing out that 'criminal executions should be as much avoided as possible', went on to suggest that in 'particular atrocious cases' it would create 'a greater terror' if the offender was 'hanged in secret and then thrown immediately into a private hole dug for them in a part of the prison ... and quicklime thrown over the dead body'. 96

In the third quarter of the eighteenth century two other death penalty-related punishments were also discussed, both of which involved subjecting capital convicts to the danger of dying whilst still offering the possibility, or even the probability, of survival. One of these, suggested by a Norwich correspondent of the Gentleman's Magazine, involved a bizarre form of half-hanging, which all felons apart from murderers would be eligible for. 'The convict should be hanged', the article suggested, 'but instead of being suspended for an hour let it be only for one minute, or less, in which time he will be as dead to his own sense offeeling, and as much punished, as if he were kept hanging the usual time ... Would not a man thus brought again on the stage of life become ... a more useful member of society?? 97 
There is no evidence that this proposal was ever actually considered by government, but the other death-penalty-related punishment suggested in this period was taken much more seriously and came within days of being put into practice in London.

This punishment was first mooted just a few years after the Murder Act, as a reaction to its lack of success. In 1755, a letter to the Gentleman's Magazine argued that since 'the late laws' had had so little impact on 'the frequency of murders ... instead of giving the murderer's body to the surgeons when it is dead, he should be put into their hands alive and subjected to such experiments as can only be made on a living subject'. Several diseases, the correspondent argued, 'might possibly be cured by chirurgical operations so dangerous that the experiment is not likely to be made, even in our hospitals'. Surely, the writer argued, 'notorious criminals might justly be reserved for these operations' provided that they were not 'wantonly mangled to gratify mere curiosity', and as long as these experiments were only done 'under the direction of persons properly appointed'. ${ }^{98}$ Eight years later this was precisely the role that Thomas Pierce, who wished to test 'a styptic capable of stopping the most violent bleedings', petitioned the government to allocate to him. The styptic having been 'tried with success on brute creation', he asked that he now be allowed to experiment on the 'amputated limb' of a criminal under sentence of death, one of whom, George Clippingdale, had agreed to be subjected to the operation. ${ }^{99}$ George was temporarily reprieved while the government consulted 'His Majesties serjeant surgeons', and was eventually transported when the latter advised the King against the experiment. ${ }^{100}$ However, Pierce did not give up. Four years later he tried again and obtained the King's permission to perform the same experiment on another capital convict, John Bonham. ${ }^{101}$ The 23rd June was appointed as the day for the experiment, and the newspapers not only announced the granting of a royal pardon on condition that Bonham undergo the operation but also carried an advertisement informing the 'gentlemen of the faculty' that if they wished to witness the amputation they needed to obtain tickets. ${ }^{102}$ However, the King changed his mind at the last minute, and Bonham became the second convict to avoid the gallows by this route. ${ }^{103}$

The debate did not end there. In his Observations on the Statutes, published in 1769, Barrington praised the idea that criminals 'should be pardoned on condition that some hazardous experiment for the promotion of medical knowledge may be tried upon them'. ${ }^{104}$ Three years later, however, Eden, while recognizing the 'seeming liberality' of subjecting 
'certain classes of criminals to medical experiments for the benefit of mankind', argued that 'such a plan can never with any propriety receive ... legislative sanction', and it never appears to have done so. ${ }^{105}$ Like the pre-1752 proposals that criminals should be subjected to castration this punishment was not strictly speaking an aggravated form of the death penalty, because the convict had at least some chance of recovery, but it was put forward as an alternative to the Murder Act and seriously considered by the government even though it was ultimately rejected. During the period from 1752 to the penal crisis of the mid/late 1780s the structure of post-execution punishments created by the Murder Act therefore came under considerable criticism, and although the alternatives suggested were relatively limited compared to earlier periods, thought was also given to new methods of punishment that might augment the Act. However, the repeal of the Murder Act was never seriously suggested in this period and the broad acceptance that the Act received was also indicated by the wide range of proposals that were made to extend dissection or hanging in chains (or both) to other types of offender apart from murderers - proposals that came nearest to reaching the statute book during the debate on the government-backed bill of 1786 .

\section{Proposals to Extend the Post-execution Provisions of the Murder Act to Other Offences}

In the first three-and- a-half decades after the Murder Act a considerable number of commentators advocated a variety ofextensions to the Act and to post-execution punishment more generally, which suggests that, although the Murder Act was often criticized, it was also by this point a very broadly accepted plank of penal policy—and could therefore be seen as a plank that was worth building on. Three specific types of extension to the Murder Act were proposed during these years. The first involved the punishment of suicides. Debates about the potential usefulness of dissection in the mid-1750s produced a proposal that those who committed suicide should be delivered to the surgeons for dissection, and ten years later-faced by what was perceived to be the daily increase of suicidesanother writer suggested that since 'no terror ought to be omitted' to suppress such a crime, 'exemplary shame should be inflicted on them' by their being publicly dissected. ${ }^{106}$ In 1769 an article in the Middlesex Journal went a stage further suggesting not only 'that the bodies of 
suicides should be publicly anatomized' but also that their skeletons should be 'hung up in Surgeons Hall'. ${ }^{107}$ That venue would not, however, have provided enough niches and another commentator suggested a way round this - that the bones of suicides should be exhibited in a special 'charnel-house' 'in which monuments should be erected giving an account of their deaths' ${ }^{108}$ As late as 1790 other commentators, including John Wesley, were still suggesting hanging in chains as an alternative, 'if nothing else be likely to deter men from so heinous an offence against reason', ${ }^{109}$ but (with the exception of capital offenders who committed suicide in prison) no record has been uncovered of suicides being gibbeted anywhere in England. ${ }^{110}$ Nor was dissection, or dissection followed by the public exhibition of the suicide's skeleton, ever enacted in England in relation to suicides. However, the latter combination was very actively advocated for several other types of offender. ${ }^{111}$

This double-pronged approach, involving both dissection and gibbeting, constituted the second major extension of the Murder Act proposed in this period. In 1761, after a sentence of hanging in chains had been handed down against a Swiss painter who had killed his landlady, it was suggested that since gibbeting rather than dissection 'may appear to some people not an increase but a mitigation of the punishment' it would be best to join both these punishments together by 'having the body first anatomized and dissected, and the skeleton afterwards hung in chains'. ${ }^{112}$ This double punishment was also advocated during the 1760s in two angry articles that demanded further penal sanctions against particular types of murder. The first, published in 1768 after the Wilkite riots, suggested that magistrates responsible for 'firing upon innocent persons' and 'wantonly murdering' them should be punished 'not merely by hanging and sending their bodies to a surgeon, but by being hung in chains near the spot where they issued their ... bloody orders'. ${ }^{113}$ The other article, which focused on murders in duels, suggested not only that the surviving duelist be hanged and dissected under the Murder Act but also that the man killed in the duel should be hanged upon a public gibbet for a certain time (presumably short) and then given to the surgeons. ${ }^{114}$

This latter suggestion incorporated an element of the third type of Murder Act extension advocated in this period, that is, those that advocated including new categories of criminal corpse in its provisions. The public gibbeting and dissection of the corpses of men who had been murdered during the very small proportion of duels, which came to the notice of the courts, would not have significantly increased the numbers 
subjected to post-mortem punishment. However, the various commentators and potential legislators who advocated the extension of the Murder Act's provisions to many other types of capital offenders would, if they had been successful, have achieved precisely that.

The mixture of motives that lay behind these suggestions is not always easy to unravel but two main strands can be identified. First, the surgeons' need for more cadavers, and the desire to discourage the growing body-snatching trade that the unfulfilled need had generated, were undoubtedly important. 'Anatomy is certainly of great advantage to the community', a newspaper noted in 1766, but 'the great number of professors of anatomy in this vast metropolis cannot be supplied with a sufficient number of subjects ... What the gallows supplies are but few'. Grave robbery was therefore, he argued, bound to be prevalent. ${ }^{115}$ A decade later in 1776 a letter to the Middlesex Journal, having pointed out that body-snatching had reached 'an enormous height', put forward the same arguments about the great increase in surgeons and about the 'few bodies' that the law gave them, to support the idea that the anatomy teachers should petition Parliament for an act stipulating 'that the bodies of all housebreakers, robbers, forgers, coiners' and all other capitally convicted convicts 'be immediately after execution delivered to the surgeons for dissection ... as the bodies of murderers have usually been'. 'I have not the least doubt', the writer confidently concluded that this 'praiseworthy measure ... would be granted' if the case was properly made. ${ }^{116}$ Anger at body-snatching continued to grow. In 1777 two 'resurrection men' were nearly 'pelted to death' by the London crowd, prompting calls for a new method to be found 'to procure a sufficient number of subjects' for the surgeons. ${ }^{117}$ By the early 1780s a major crisis about body snatching was brewing in London and in May 1785 one of the capital's main surgeons was prosecuted for conveying away dead bodies for dissection'. ${ }^{18}$ In October that year disgust 'at the means taken to procure bodies for dissection' led one correspondent of The Times to suggest that 'as it is essential ... that lectures should be held on the bodies of the dead' a law should be passed enabling 'the bodies of executed felons' to be sold to the surgeons. ${ }^{119}$ This growing awareness of the problems being created by the inadequate supply of cadavers to teachers of anatomy was, as Ward has recently pointed out, the main initial reason why (only seven months after The Times article was published) Wilberforce introduced his bill 'for regulating the disposal of the bodies of criminals ... condemned and executed for certain heinous offences' including rape, arson, burglary and highway 
robbery with violence. ${ }^{120}$ However, that bill, and in particular its active sponsorship by the government, also arose out of a second, and completely different, set of concerns.

In the early to mid-1780s crime rates increased rapidly following the demobilization at the end of the American war. The level of capital convictions rose in parallel and so did the percentage being executed. ${ }^{121}$ Transportation to the USA was no longer an option and many voices were demanding increased severity and a reduction in the pardoning of capital offenders. $^{122}$ As a result by the mid-1780s more offenders were being hanged than had been the case for nearly 200 years. In 1785156 people went to the gallows for property offences alone in London and the Home Circuit counties. Twenty of these were hung outside Newgate on one day in early February 1785, prompting The Times to launch a highly critical campaign. Fewer executions had occurred in all the cities of Europe during the last year than were to take place in one day in London, it pointed out. 'The long and dreadful list of persons ordered for execution' will astonish 'every country in Europe', who 'will naturally suppose that in England there is no more government than in a horde of wandering tartars'. ${ }^{123}$ The unprecedented number of hangings was partly caused by a rise in robbery prosecutions, but an important role was also played by the rapid rise of burglary convictions, which outnumbered robbery prosecutions for the first time in the mid-1780s, and had a particularly heavy impact on the numbers being hanged because a very high and rising proportion of burglars failed to get pardons and therefore ended up on the gallows. ${ }^{124}$ Faced by these mass hangings and by the growing criticism they were attracting, some members of Parliament clearly turned their minds towards the use of post-execution punishment. A few days after the publication of this critical article in The Times, it was reported that 'a bill will be brought to Parliament directing the bodies of all persons executed for burglaries to be given immediately after their sentence takes place, to the surgeons for public dissection'. ${ }^{125}$ In April 1785 the hanging of nineteen more offenders in one day brought a renewed attack in the press. 'The carnage of yesterday is a disgrace' The Times announced, while arguing simultaneously that the capital code was 'failing to prevent the commission of crimes' and that 'the frequency of capital punishments has evidently done away with the awe and example of untimely death. ${ }^{126}$ In the same month Commodore Thompson, one of the government's advisors on the establishment of penal colonies, also suggested the introduction of post-execution punishment as a response to this crisis. Building on the proposal made two months earlier 
in relation to burglars, he suggested expanding the use of post-execution punishment much further. 'The many executions of late and the increase of crimes ... leads me to recommend', he wrote in a letter to the Home Secretary, 'ordering every body for dissection that was executed'. ${ }^{127}$ Thus when Wilberforce introduced his prospective bill to Parliament a year later he did so in the context of previous discussions about both the surgeons' need for cadavers, and the wider use of dissection as a possible response to the acute penal crisis of the mid-1780s.

\section{The 1786 Bill: Attempting to Expand the Remit OF THE Murder ACT}

Two excellent recent articles have explored, from slightly different angles, the origins, context and nature of Wilberforce's 1786 bill, and the reasons for its failure. ${ }^{128}$ Richard Ward's work, by uncovering the importance of the Yorkshire surgeon William Hey (a close friend of Wilberforce) as a key originator of the Act, has emphasized the role of the growing demand for cadavers. ${ }^{129}$ Devereaux's article, by contrast, is particularly strong in its analysis of how the bill may have fitted into the broader response of Pitt's government to the penal crisis of the mid-1780s. ${ }^{130}$ Readers wishing to understand in detail the roles of Wilberforce, Hey, Pitt and the bill's main opponent-Lord Loughborough-should consult these works. In this study we will look at the 1786 bill, and at a similar but the less successful bill suggested to Parliament in 1796, which advocated dissection for burglars and robbers-from a rather different perspective. These two bills, and particularly the government-backed 1786 legislative initiative, resulted in a series of relatively well-recorded debates and these will be used here to gain rare insights into how the Murder Act was regarded three or four decades after its introduction.

Although during the first parliamentary debate on the bill in May 1786, Wilberforce made much of 'the extreme difficulty which surgeons experienced in procuring bodies for dissections' ${ }^{131}$ and of the problems of preventing the 'stealing of corpses from churchyards', ${ }^{132}$ and although some newspaper reports suggested he made no reference to criminal justice matters, this was not the case. He specifically referred to 'the hope of deterring many persons' from committing capital crimes, and this penal context was also highlighted by Dundas's contribution to the same debate. ${ }^{133}$ When the bill finally emerged, after being redrafted with the 
help of the government's law officers, it differed in two important respects from Wilberforce's initial proposal that (as it was reported in the General Evening Post) 'the bodies of all persons executed for capital crimes should be delivered ... for ... dissection'. ${ }^{134}$ First, the categories of offenders covered by the bill were more limited. Burglary, violent robbery, arson and rape were the main types of offence that fell under its provisions. ${ }^{135}$ However, since these offenders represented the bulk of the convicts sent to the gallows, this would still have increased the use of dissection five or six fold. ${ }^{136}$ Secondly, the corpses of these offenders would not all have been 'delivered to the Surgeons' Company' as Wilberforce had proposed. ${ }^{137}$ A short clause in the bill stipulated that "nothing in this act ... shall ... prevent any judge ... from appointing the body of the offenders aforesaid, to be hanged in chains'. ${ }^{138}$ The judges already had the right to gibbet these offenders. The bill simply added the dissection option and insisted that one of these two post-execution punishments be stipulated in the sentence. The penal options it wished to impose on this much wider range of offenders were therefore precisely the same as those in the Murder Act.

Devereaux's excellent, if sometimes inferential, reading of the evidence suggests that the government's aim in backing this bill was not as harsh as its wording implies. Faced by the transportation crisis, the failure of the London Police Bill of 1785 and most of all by growing criticism of the huge numbers going to the gallows, Pitt backed Wilberforce's measure because he wanted to steer a middle path between the desire to execute fewer criminals and the desire to punish those that were executed with more exemplary severity. ${ }^{139}$ With the Government's backing the bill passed through every stage in the Commons and even got through the committee stage in the Lords before hitting the opposition and invective of one of the leading judges, the future Lord Chancellor, Lord Loughborough. ${ }^{140}$ Loughborough's reasons for opposing the bill were complex and have been analysed in detail elsewhere. ${ }^{141}$ His opposition may have been motivated mainly by personal or political priorities and he was certainly no friend of Pitt's administration. He also appears to have been angry that the twelve judges had not been properly consulted. In a lengthy and wide-ranging speech he portrayed the bill as cruel, inaccurate, loosely worded and serving to remove the judges' vital right to reprieve offenders. Whether these criticisms were entirely fair or accurate is a matter for debate, as are Loughborough's motives in view of his reputation for changing side politically whenever it suited him. ${ }^{142}$ However, his remarks do contain 
some very interesting reflections on the Murder Act and on the importance of differentiation in the punishment of offenders.

One of Lord Loughborough's most substantial arguments was that the 1786 bill would undermine the very positive impact that the Murder Act had achieved. The 1752 Act's 'taking away the right of burial and destining the body of the criminal to dissection' had 'been found of essential advantage to the community', he argued. When informed that they were going to be dissected he had observed that many criminals 'trembled and exhibited ... the extremist horror', which also made a 'forcible impression on the minds of the bystanders and ... was attended with the most salutary consequences'. He and his fellow judges had seen 'repeated instances' of the good effects of the Murder Act's additional punishments. Given that the Murder Act had contributed so much to the 'morals of mankind and to the good order of the community', he asked 'was it wise therefore to destroy the salutary effect' by making dissection and the loss of burial rights 'an ordinary consequence of every conviction of almost every capital offence?" ${ }^{143}$ The bill, he went on to argue, 'lost sight of all distinction between crimes of very different magnitude'. Were 'the man who deprived a fellow creature of life and he who lifted a latch and stole the most trifling article ... equally deep in guilt?' Were 'the man who committed a violence on a common prostitute, and he who robbed a virtuous woman of what she held most dear' to be treated without admitting any distinctions? ${ }^{144}$ To pass the promiscuous sentence of dissection on all of them would, he argued, be to destroy the positive impact of the 1752 Act, the preamble of which he then had read to the House. Loughborough also defended the Murder Act on other grounds. If the new bill was passed and 'the same punishment ... attend the convict for burglary as for murder, breaking open a house would generally be attended with murder', he argued. He also praised the Murder Act for its role in reinforcing the superior nature of the English criminal justice system because, by using an extra punishment that involved 'no great degree of personal pain', it ensured that, unlike 'other states', England used no punishments (such as 'breaking on the wheel') that were attended with 'aggravated severity and cruelty'. ${ }^{145}$

Whether all the other judges felt quite as positive about the 1752 Act as Loughborough purported to be, remains unclear. However, the fact that not one of the Lords sitting that day, voted in favour of the bill ${ }^{146}$ and that Loughborough confidently claimed during the debate that many of his fellow judges felt as he did, suggests that the Murder Act still had the broad support of those on the bench, despite the criticisms sometimes levelled at 
it. The debate that was generated in 1796, when Richard Jodrell briefly attempted to get the Commons' permission to introduce a bill that would have sent all burglars and highway robbers for dissection, also produced evidence that key judicial figures had a positive view of the Murder Act. Sergeant Adair, a very experienced Old Bailey judge, argued that 'the law had set up this barrier between murder and all other crimes' and that it would be very unwise to break it, and several others opposed the bill on similar grounds. The Attorney General argued, in addition, that the Murder Act had acted as a major deterrent to violence. 'The experience of those who were employed in administering the criminal law', he suggested, 'frequently have shown them how often the dread of anatomization had arrested the arm uplifted to commit murder', ${ }^{147}$ (though how any of the judges would know this had happened remained unexplained). However, although the 1786 and 1796 debates induced several important legal figures to make strong and detailed defences of the use of penal dissection under Murder Act-defences that some of them continued to advance until the early 1830s - it was also in the later 1780s and the 1790s that the tide began very gradually to turn against the use of the other post-execution punishment the Act had relied on-hanging in chains.

\section{1786-1808, the End of Burning at the Stake and of Support for Hanging in Chains}

Ironically, the first eighteenth-century Act that removed at least one category of offenders from the risk of being subjected to aggravated or post-execution punishment was first mooted in Parliament by Wilberforce during his attempt in 1786 to greatly widen the range of offenders subjected to dissection. On June 23rd 1786, two days after the public burning at the stake of Phoebe Harris for coining, Wilberforce asked Parliament to instruct those involved in drafting his bill 'to insert a clause for ... altering the punishment of females convicted of petty treason'. ${ }^{148}$ The newspapers had reported in detail the four-hour process by which Harris's body had been reduced to a small pile of ashes and bones in the street outside Newgate and they had been extremely critical. This 'inhuman execution ... is a disgrace to our laws' one concluded, while The Times described it as 'a scandal upon the law ... inhuman ...indelicate and shocking' ${ }^{149}$ Wilberforce's request, which was almost certainly a reaction to this event and its coverage, was immediately granted by the Commons, ${ }^{150}$ and a 
clause ending the punishment of burning at the stake was duly inserted into the 1786 bill, was objected to by Lord Loughborough and was then rejected with the rest of the bill. ${ }^{151}$ However, almost exactly four years later a new bill, introduced after two further burnings and a furious campaign in The Times, ${ }^{152}$ passed fairly easily through Parliament and burning at the stake, and the obliteration of the offender's corpse, which it inevitably involved, was abandoned. ${ }^{153}$ For the 'high treason' offence of coining females were now, like their male counterparts, simply to be drawn and hanged, thus removing the post-execution element of their punishment. However, the corpses of female murderers found guilty of petty treason did not avoid post-execution punishment under this new act. They were now publicly dissected under the Murder Act rather than being reduced to ashes. ${ }^{154}$

As Devereaux's detailed account of the passing of the 1790 Act has pointed out, the abolition of burning women at the stake was not, as some historians have suggested, simply an inevitable product of the increasing impact of 'enlightened attitudes towards punishment'. ${ }^{155}$ The timing of the Act is better explained, he argues, by the conjunction of four more specific changes - an unprecedented rise in the number of female coiners being subjected to burning at the stake ${ }^{156}$; the transfer in 1783 of the place of execution from Tyburn to the street outside Newgate, which meant that the burnings were now performed in a crowded urban thoroughfare where residents could not avoid seeing them; a growing sensitivity to the public punishment of women; and, most importantly, the increasingly overt hostility of London's sheriffs whose role it was to conduct these burnings. ${ }^{157}$ However, while this particular conjunction of factors may explain the specific timing of the 1790 Act, broader changes in cultural attitudes to punishment undoubtedly also played a role. As Devereaux points out, 'that only three such executions in the late 1780s could have the decisive impact they did speaks volumes for some kind of basic transformation in ... public sensibilities over the long term'. ${ }^{158}$ The sheriffs of earlier periods had not agitated for the repeal of the petty treason laws after being forced to put them into practice. By the late 1780s they were publically doing just that, and it was one of their number who introduced the 1790 Bill in the Commons. ${ }^{159}$ It is therefore difficult to explain this turnaround in attitudes without some reference to broader long-term changes in attitudes and sensibilities.

The extensive press criticism of burning at the stake between 1786 and 1790 was part of a much broader critique of capital punishment, which forced the government to institute policies that would drastically reduce 
the huge numbers reaching the gallows. In 1788-1789 the numbers executed fell more than three-fold compared to their peak levels between 1785 and 1787, because Pitt used the backlog of pardoning decisions created by the King's temporary illness as an excuse to drastically cut the percentage of capital convicts that were executed. ${ }^{160}$ This new policy then continued for the next decade. Between 1790 and 1799 an average of nineteen property offenders were hung in London each year. Between 1785 and 1787 the average had been seventy-eight. ${ }^{161}$ The government had been forced by the mid-1780s crisis, and the negative press coverage it created, both to repeal the laws relating to burning at the stake and to institute a drastic cut in the proportion of London's offenders being hanged, which had a long term impact on the administration of the Bloody Code in the capital. After a brief rise in the famine year of 1800 the number of hangings in London halved again between 1801 and 1810, averaging only nine per year and reaching an all-time low of three in 1808 . $^{162}$

The huge reduction in the number of offenders hanged in London, combined with the end of the transportation crisis and the newspapers' obsession with the revolution unfolding in France, meant that criticism of the capital code was more muted in the early to mid-1790s, but important elements of that criticism clearly influenced the parliamentary debate on Jodrell's 1796 proposal that dissection should be introduced for all burglars and robbers. The Attorney General used the occasion to point out that capital punishment for burglary was already thought by many to be too severe, while Sergeant Adair argued strongly against the proposal partly on the grounds that 'the complexion of our criminal laws were already too sanguinary and severe', and that 'it was a painful reflection to think that it [the death penalty] was not entirely reserved for murder and high treason'. ${ }^{163}$ The ideas voiced by these speakers were part of what John Beattie has termed 'the mental sea change' that lay behind the late-eighteenth century 'withering of support for a penal system that depended fundamentally on the threat of execution'. ${ }^{164}$ A many-stranded critique was emerging. A correspondent of the Gentlemen's Magazine, for example, argued in 1790 that

the laws of England ... are cruel, unjust and useless. The number of our fellow-mortals hung up so frequently like the vilest animals is ... proof of their cruelty; the same punishment inflicted on the parricide and the man who takes three shillings ... is a proof that they are unjust; the frequency of crimes ... is proof that they are useless. ${ }^{165}$ 
This change in attitude had important implications for the future of post-execution punishment in England. In attacking the underlying assumptions that supported the use of the gallows, the reformers used a range of arguments many of which were not only applicable to post-execution punishments but also had particularly strong critical purchase in relation to burning, gibbeting and, to a much lesser extent, dissection.

In his work on the body and punishment in the later eighteenth century McGowen has argued cogently, for example, that as the treatment of the criminal body gradually ceased to be a metaphor for expunging threats to the health of the social body, the reformers were able to replace this discursive framework with a new focus on the fate and experience of the individual, which in turn 'produced a demand for different punishments in part because the inflictions suffered seemed so disturbing and negative'. ${ }^{166}$ 'The spectators seem to contemplate not the punishment of a criminal, but merely the death of an individual', Romilly wrote in 1786. 'They go away impressed' not by 'the justice of the law', but by 'compassion for a fellow creature, to whose suffering they have been witnesses'. This argument that, to quote McGowen, 'the mistreatment of the body prevented observers from seeing the social necessity of punishment' was clearly equally applicable to post-execution punishment. So was another argument frequently used by opponents of capital punishment, that is, that the gallows produced insensitivity and hardened the hearts of both the crowd and the criminals themselves. ${ }^{167}$ 'Barbarous spectacles of human agony' and 'cruel or unseemly exhibitions of death' were opposed by Paley in 1785 'as tending to harden or deprave the public's feelings' - and a year later The Times echoed this sentiment in its comments on the burning of Phoebe Harris. 'Sanguinary and terrible punishments' it argued, quoting Montesquieu, 'tend to harden the human heart'. ${ }^{168}$ Eden not only observed that 'the sensibility of the people, under so extravagant an execution of power, degenerates into despondency, baseness and stupidity' but also suggested that hanging in chains was particularly likely to generate these responses. It could not be doubted, he argued after being relatively positive about dissection, that the inevitable effect of forcing citizens to view 'gibbets ... crowded with human carcasses' would be 'to blunt the sentiments and destroy the benevolent prejudices of the people'. ${ }^{169}$

This was not the only argument put forward by the lateeighteenth-century penal reformers that was easily and frequently turned into a critique of post-execution punishments. The growing sense-created 
by the combination of mass executions and continually growing indictment rates $^{170}$ - that the gallows rituals were not conveying any effective messages and that capital punishment was not working as a deterrent (which even the Solicitor General had to accede to during the 1785 London Police Bill debate) was paralleled by a long-running critique of the efficacy and morality of post-execution punishments and more particularly of hanging in chains. ${ }^{171}$ Although the dissection of murderers was criticized in 1794 for failing to be 'any preventive to others for the future commission of such crimes', and for providing 'so small a distinction in the punishment' of the murderer and the thief, ${ }^{172}$ by the 1790 s and early 1800 s it was hanging in chains that was the main target of disapproval. 'The exhibition of lifeless carcasses on gibbets ... cannot be viewed by the humane and feeling without horror', wrote Beccarius Anglicus in a long diatribe against gibbeting. Echoing Blackstone, he then pointed out that, 'to prevent the brutalizing effect of such spectacles', Jewish law only allowed offenders to be left suspended for one night, whereas in England the country was 'polluted' by leaving them 'suspended on gibbets till their flesh has mouldered away or been devoured by the fouls of heaven'. He then entreated the English judges to discontinue this 'disgusting' practice of allowing the law 'to pursue the offender beyond the portals of mortality and to vent its fury on his senseless form'. ${ }^{173}$ In 1799 another writer on capital punishment, having argued that 'dissection, if performed with proper decency and in the presence of persons who are studying anatomy, may tend to the advancement of science', then launched into an equally strong critique of hanging in chains. 'This ... is productive of very little or no good' he argued. 'How many times are robberies and murders committed very near and even under a gibbet?'. The practice is, he suggested, 'disgraceful to a civilized nation; and while it fails in the intention, which is that of deterring the atrocious offender, it must shock the tender traveler, whose sensations are awake to the shocking degraded situation of a loathsome carcass'. ${ }^{174}$ This critique was echoed in a wide range of London newspapers in the later 1790s, which frequently carried reports of crimes committed around the capital's gibbets. The St James's Chronicle, for example, reported in 1796 that 'The Chester Mail was robbed within 100 yards of the gibbet on which Lewin hangs, who suffered for a similar offence two years ago'. ${ }^{175}$ Abershaw's gibbet on Wimbledon Common, on which the corpse of another highwayman was displayed, was the scene of a considerable number of widely reported robberies between 1796 and $1800,{ }^{176}$ as well as being the site in 1798 of a duel involving 
Prime Minister Pitt-an act which could technically have resulted in Pitt being gibbeted had he killed the radical MP who had challenged him. ${ }^{177}$ By this time both the gallows and the gibbet were not felt to be performing their most vital function-deterrence-and the latter in particular was therefore in danger of appearing not only cruel and highly distasteful, but also superfluous.

Broader changes in penal policy and discourse were beginning to move decisively away from punishments such as hanging in chains by the final quarter of the eighteenth century. Physical publically inflicted punishments directed at the body, symbolized by the gallows, the pillory and the gibbet were giving way to private, non-physical and mainly prison-based sanctions directed at the mind and aimed at generating the reform of the offender, as can be seen in the rapid growth in the use of imprisonment to punish property offenders and in the building of new penitentiary-style prisons in several counties. ${ }^{178}$ The solitary cell hidden from contact with the world, rather than the solitary corpse gibbetted by the roadside was becoming the new focus of attention in late-eighteenth-century penal debate. Historians are deeply divided about whether we should see this movement from the gallows to the prison as simply a new and deeper strategy of control and social discipline, or as a function of a fundamental change in sensibilities towards violence. ${ }^{179}$ However, punishments relying on the public display of rotting, burning or newly dismembered corpses were inevitably going to come under increasing scrutiny as this movement gathered momentum.

By arguing that the later eighteenth century witnessed a turning away from public execution rituals designed to 'bombard the visual senses' of the viewers, to 'increasingly hidden punishment that relied upon the imagination to conjure up frightening images of the unseen', Steven Wilf's work on 'execution aesthetics' has suggested another related way in which changing penal sensibilities may have undermined support for post-execution punishment. ${ }^{180}$ His argument is not always convincing. Devereaux has shown, for example, that this was clearly not the reason why the gallows was moved from Tyburn to outside Newgate in 1783, since that change was mainly designed to make public executions more effective. ${ }^{181}$ However, Wilf's work has usefully spotlighted the significance of another potentially influential strand of contemporary penal discourse, by pointing out that 'the 1780s witnessed a growing number of proposals for various forms of private executions. ${ }^{182}$ This idea had been floated by Henry Fielding a year before the Murder Act. 'I question whether every object is not lessened by being looked upon', he argued. If executions were 
private 'they would be much more shocking and terrible to the crowd outdoors ... as well as more dreadful to the criminals themselves'. ${ }^{183}$ However, opposition to this idea remained very strong. As one legal writer put it in 1759 'No criminal ought to be executed in the dark'. Not only would there be 'some risk that an innocent person, either by accident or design, might be made to suffer for the guilty' but the whole purpose of public execution-'to strike terror into the spectators'-would be lost. ${ }^{184}$

The idea of private executions was revived in the 1785 when The Times, searching for a way to reinvigorate the deterrent effect of the gallows, published two proposals on these lines. After arguing that hanging in secret 'would strike a greater terror' the paper went on two months later to make a more detailed suggestion: 'Let us now try what terrors may arise from the certainty of being cut off in the privacy of an inclosure to which none can be admitted but the necessary officers, and from which all ... who might afford consolation are excluded', it suggested. The effects of such executions would not 'be blunted by frequency', it then argued, 'for as the whole apparatus would remain always invisible to the multitude, every repetition ... would never lose the force of novelty'. ${ }^{185}$ William Paley's proposal in 1785 that criminals should be fed to wild beasts also included a proviso that they should 'perish in a manner dreadful to the imagination yet concealed from view', ${ }^{186}$ and in 1787 the Gentlemen's Magazine went further, demanding 'an act of parliament ... for conducting the punishment privately in the press yard' after which, if required, 'the corps should be exposed on a stage before the prison'. This temporary gibbeting was designed to create terror in the minds of the common people 'by playing on their imaginations' for 'they would suppose cruelties in the executioner which had not been practiced'. ${ }^{187}$ Fears that hidden punishments threatened English liberties meant that these ideas were never fully developed in the eighteenth and early-nineteenth centuries and public executions were not abandoned until 1868. ${ }^{188}$ However, these proposals indicate both a growing desire (which can also be observed on the continent) to move the offender's body away from centre stage in the rituals of execution ${ }^{189}$ and a broader sense that visual spectacles were often highly problematic-both ideas that raised increasing questions about the use of hanging in chains. These changes in the underlying discursive structures that were shaping penal policy, combined with the gradually developing sense from the mid-1780s onwards that exposure to decaying bodies was unhealthy and potentially dangerous, ${ }^{190}$ clearly raised big questions about the continued use of hanging in chains, and in this context the eventual collapse of 
gibbeting just after 1800 (which we saw in Chap. 3) seems almost inevitable. It does not, however, explain the incredibly sudden and complete ending of the gibbeting of property offenders in 1802 (Fig. 3.2) and the almost complete collapse in the proportion of murderers who were hung in chains which is observable from that moment onwards (Fig. 3.1).

To understand why gibbeting collapsed so suddenly as a substantial penal practice in the first two or three years of the nineteenth century we need to see it in the context of the simultaneous changes that occurred in two other aspects of the administration of capital punishment. The first of these involved the related but separate practice of hanging offenders at the scene of their crime. As Steve Poole's recent work has shown crime-scene executions followed a very similar pattern of decline. Having peaked in the 1780s at more than three a year, this type of execution then declined to only one every other year 1806-1810 and one per decade 1821-1830, after which their use completely ceased. ${ }^{191}$ The decline was particularly rapid in the metropolis. Thirteen London convicts were hanged at the scene of their crimes 1785-1795. None suffered that fate after $1816 .^{192}$ Since a very considerable number of crime-scene executions also involved gibbeting, the long-term correlation between these two changes is hardly surprising, but many crime-scene hangings did not include hanging in chains and the decline of the former therefore indicates another deliberate policy change. Since the judges increasingly ignored this option and the government encouraged them to do so by refusing to reimburse local sheriffs for the very considerable expenses involved (unless the offence involved some form of social unrest), ${ }^{193}$ the authorities clearly decided to turn away from the crime-scene execution option in the first decade of the nineteenth century. Moreover this period also witnessed a much more fundamental change in execution policies.

In 1801-1802 those in charge of the administration of the capital punishment system in England and Wales suddenly instituted a more merciful approach to thepardoning of capital offenders. Between Pitt's rethinking of pardoning policies in 1788 and the famine year of 1800 just over $25 \%$ of those capitally convicted at the Old Bailey were hanged. This fell in 1801-1804 to less than 10\% and although it rose briefly in mid-decade it then fell to an all-time low of around 5\% in 1808. This meant that between 1801 and 1810 the average execution rate was half that experienced between 1788 and 1800 and about one-fifth of the rate in 1785-1787, a pattern that continued (apart from a brief period in the late 1810 s and early 1820s) until the repeal of most of the capital code in the 
early 1830s. ${ }^{194}$ Moreover, Douglas Hay's recent calculations on pardoning rates across all of England and Wales suggest that an equally sudden change also took place outside London. The percentage of all capital convicts left to hang fell from around $30 \%$ in $1800-1801$ to about $18 \%$ in $1802-1803$ and, despite similar fluctuations as those seen in London by the mid-1820s it was only slightly above 5\%. ${ }^{195}$ The Bank of England's aggressive prosecution policies meant that hanging rates for forgery did not fall overall, but those for robbery and stealing from houses nearly halved across England and Wales between 1800 and 1803. ${ }^{196}$ Gatrell has argued that, following the massive increase in prosecutions for capital offences that occurred in late 1810s and 1820s, after the huge post-war demobilization of 1815, the system of capital punishment effectively collapsed under its own weight. ${ }^{197}$ However, the judges appear to have made a decisive change between 15 and 20 years before this by largely abandoning gibbeting and crime-scene execution, and by simultaneously reducing more than two-fold the proportion of capital convicts that they left to hang.

The reasons for this change of policy were never explained, and the change itself was never publicly announced, but it is possible that Lord Eldon, who became Lord Chancellor in 1801, may have been at least partly responsible for it. He later claimed that in 1801 he had initiated a new means of restraining the numbers subjected to the death penalty in London, and it is certainly true that execution rates for the group he particularly singled out-those convicted of robbery-halved between Lord Loughborough's chancellorship 1793-1800 and Eldon's first decade in charge (1801-1810). ${ }^{198}$ Was the new Lord Chancellor also responsible for persuading both the Old Bailey and the circuit judges to completely abandon the gibbeting of property offenders in 1801 and to confine the gibbeting of murderers to only two occasions $1802-1810$ ? $^{199}$ On the surface this seems unlikely since Eldon was a staunch defender of the death penalty, as was Lord Ellenborough who became Chief Justice in 1802, ${ }^{200}$ but whether either of these two was the prime mover, or whether the twelve judges between them decided on a new set of policies, ${ }^{201}$ there is no doubt that the collapse of gibbeting was part of a much broader rethinking of penal policy in 1801-1802, which also involved a major movement downwards in execution rates and a rapid decline in the use of crime-scene hangings. By 1808, the year in which Romilly launched his parliamentary attack on the Bloody Code, ten months would pass by without a single hanging in London, and crime-scene hangings had reached their lowest levels for nearly 100 years. ${ }^{202}$ By that year the Old Bailey judges had not 
ordered any offender to be hung in chains for nearly a decade and they would never do so again, the only criminals gibbeted in the capital after that date being the four Admiralty Court offenders hung in chains in 1814 and 1816 respectively. Between 1808 and the passing of the Anatomy Act in 1832 only three murderers (less than $1 \%$ of those fully convicted) were gibbeted by the provincial assize courts. Given that burning at the stake had been abolished nearly 20 years earlier, and that only a very small number of offenders were punished for high treason in this period, post-execution punishment was now effectively confined to one form only -public dissection.

\section{The Modification and Gradual Privatization of Post-execution Punishment, 1808-1828}

Romilly's attempts to persuade Parliament to repeal parts of the capital code in the decade after 1808 were not especially successful and his only attack on aggravated/post-execution punishments also had only a limited impact. ${ }^{203}$ In 1813 he introduced a bill 'To Alter the Punishment of High Treason', which proposed that the sentence for that crime be changed from drawing, hanging, disemboweling, beheading and quartering to simply drawing and hanging. The parliamentary debates on the 1813 bill (which failed) and on Romilly's second bill in 1814, revolved around a familiar set of issues. ${ }^{204}$ Its opponents mainly stressed two arguments: deterrence and the need for differentiation in punishment. Even though these incredibly painful procedures were now inflicted only after the executioner had made sure that the offender was dead, they would still, they argued, induce terror and thus help to prevent high treason. ${ }^{205}$ Equally importantly, they suggested, 'by confounding the punishments for high treason and common felonies' the bill would destroy all 'distinctions between crimes' and would make the punishment for murder more stringent than that for treason. ${ }^{206}$ Romilly and his supporters, by contrast, stressed that cruel punishments produced cruelty in the people. 'The real effect of such scenes', Romilly argued, 'is to torture the compassionate and to harden the obdurate'. ${ }^{207}$ Echoing their broader critique of discretionary justice, ${ }^{208}$ the bill's proponents also pointed out that the executioner was given huge discretionary powers, being left totally responsible for the punishment inflicted and for ensuring that it became a post-execution punishment rather than a torture-based execution of the living. ${ }^{209}$ 
The 'disgusting severities' of the existing law 'ought not ... to stain our penal code', they argued. It was important to have 'laws ... in unison with the manners of the times', and this dissonance between 'a gentle country and cruel laws' threatened to delegitimize the law. ${ }^{210}$ The judges who led the opposition largely won the day, but Romilly did score a minor victory. Disemboweling at least was ended. Although, unlike De Motte and Tyrie in the 1780s, the leaders of the 1817 Pentrich Rising and the 1820 Cato Street conspiracy avoided having their entrails cut out, they were still draw, hanged and beheaded, their dripping bloody heads being then shown to the crowd. ${ }^{211}$ These rituals may or may not have cowed their audiences, but as Gatrell has pointed out, the judges and arch Tories who led the opposition to Romilly's initiative clearly believed that they had that effect. $^{212}$

Given the limited concessions Romilly achieved in the 1814 Act and the fact that only 8 of the 241 men subjected to post-execution punishment in England and Wales between 1814 and the passing of the 1832 Anatomy Act were executed for treason, the 1813-1814 debates had relatively little direct impact-especially since the main form of post-execution punishment still in use by the mid-1810s-dissection-was never used against traitors and was not therefore a focus of debate. However, the dominance of dissection, and the core reasons why it was proffered to hanging in chains, was very well summarized by the final speaker in the 1814 Treason Act debate. Only one of the two options created by the Murder Act was now used, or of use, the Whig reformer Samuel Whitbread pointed out:

A discretionary power given to the judge to order them to be hung in chains ... has now been for years abandoned-it was not found to operate in the slightest degree to the prevention of crimes, while it placed before the public eye the most disgusting spectacle. The dissection of bodies has not this effect: for the public are not then shocked by any exhibition beyond the death of the criminal, and this has been found to be as useful as the former spectacle was disgusting. ${ }^{213}$

Whitbread's dismissal of hanging in chains and his observation that 'the judges never avail themselves' of their discretionary power to gibbet murderers proved slightly premature. ${ }^{214}$ There was a brief 3 -year revival of hanging in chains between 1814 and 1816 when nine murderers were gibbeted, eight of them (including four Malayan sailors) by the Admiralty Court. However, since only one offender was ordered to be gibbeted 
between 1817 and the Anatomy Act of 1832 his analysis was broadly correct. Overall his brief speech highlighted the three core features that shaped both discussions about, and the practical application of, post-execution punishment in the final two decades before 1832-the marginalization and almost complete dismissal of gibbeting; the continued enthusiasm for (or at least acceptance of) the remaining post-execution sanction, dissection; and the growing belief that dissection should no longer involve any element of 'exhibition' that might shock the public.

Gibbeting continued to attract very negative opinions throughout this period. It did still have a few advocates. Bathurst praised it during the 1813 debate and the aging Bow Street runner, John Townsend, recommended it when giving evidence before the 1816 London Police Committee, claiming that he had recently persuaded the Admiralty Court to hang two men in chains on the Thames. ${ }^{215}$ However, gibbeting was increasingly seen, and often described, as 'barbaric' and as a disgusting exhibition, a filthy and odious nuisance which had 'no other end but that of annoying the unoffending inhabitants'. ${ }^{216}$ This 'offence against public feeling' was not only useless but also, to quote a 1824 letter to the Home Office, 'revolting, disgusting and pitiable' bringing disgrace to the law and discrediting its administrators. ${ }^{217}$ Having seen his female companions scuttle below decks to avoid the sight of the Admiralty Court's Thames-side gibbets, the author of this letter then asked 'surely, sir, the days of Lewisham have passed, Tyburn, Kensington, Hounslow, Wimbledon are all freed from the sad practice, why should it be perpetuated to the disgrace and nuisance of the Port of London? ${ }^{218}$ Three years later in 1827 the inhabitants of Lincolnshire, following the example set by the Cornish nearly a century earlier, prevented Judge Best from gibbeting a murderer on a local high road. The felling of the surviving gibbets also began around this time. In 1826 the Derbyshire magistrates demolished a 10-year-old gibbet $^{219}$ and in the following year the destruction of a London gibbet was evocatively recorded in a sketch showing it lying on the ground with the bodies it had exhibited laid beside it. ${ }^{220}$ Although, as we will see, the twists and turns of the 1828-1832 debates on the ending of dissection resulted in the momentary reintroduction of hanging in chains, gibbeting was effectively dead as a sentencing option by the mid-1810s.

Whitbread's observation that dissection had a completely different effect to hanging in chains, because 'the public are not shocked by an exhibition', ${ }^{221}$ was much less accurate than his dismissal of gibbeting. Given the huge discretion given to the surgeons, dissection practices varied widely 
between regions and even between individuals. However, as Hurren's work has made clear, the public display of the criminal corpse was frequently part of the dissection process-a process that could last several days. $^{222}$ Although there is clear evidence that by the later $1810 \mathrm{~s}$ and $1820 \mathrm{~s}$ the dissection of criminal corpses was beginning to be privatized in some places, huge crowds still flocked to see the mutilated bodies of celebrity offenders such as Bellingham, who assassinated the Prime Minister in 1812, and William Corder, the famous Red Barn murderer, executed in $1828 .^{223}$ As late as 1818 a parricide and his accomplice were publically anatomized in the kitchen of the house were the murder took place and 'the bodies ... left exposed to the view of thousands'. ${ }^{224}$ By that time, however, the tide was beginning to turn. As early as 1802 the Lord Chief Justice had ruled that surgeons were not legally obliged to expose the corpse to public view during the dissection process and by the early 1810 s critiques of public dissection had begun to appear in the press. ${ }^{225}$ In 1822, for example, the governors of Leicester Infirmary decided that exhibiting the bodies of those given for dissection was 'improper' and should not be permitted. Five years later the Devon and Exeter Hospital made a similar decision and a growing number of surgeons and hospitals in other areas also began to develop nearly identical policies in the $1820 \mathrm{~s}^{226}$ The gradual privatization of dissection had only just begun as the debates on its future as a post-execution punishment reignited in the late 1820s but there was definitely movement in that direction.

The third element of Whitbread's speech-his very positive attitude to the use of dissection-was still being echoed by a number of writers in the 1820s. Although an increasing number of surgeons were beginning to develop the more hostile attitudes to penal dissection that would be partly responsible for its demise in 1832 , dissection was still seen by many as an appropriate response to murder. ${ }^{227}$ Moreover, several writers continued to echo the late-eighteenth-century proposals of Wilberforce and others by advocating its use against other types of offenders. In 1826 John Disney included in his 'Outlines of a Penal Code' both a general recommendation of dissection as operating strongly in preventing murder, and specific laws that would have mandated dissection 'in all cases of capital convictions' (including high treason) and for all suicides. ${ }^{228}$ In the same year a letter sent to the parliamentary committee on criminal convictions advocated both the repeal of some capital statutes and the use of dissection against all those who were still executed, in part as response to the growing problem of body snatching. ${ }^{229}$ That problem had already inspired two articles in the 
Gentlemen's Magazine in 1814 and 1821 advocating in the first case that 'the body of every criminal that is executed' be given to the surgeons, and in the second that suicides and those 'killed in a duel' should be sent for dissection along with all those who died 'by the hands of justice' in order to supply the surgeons' needs and 'stop the trade of the resurrection men'. ${ }^{230}$ Although, as a public event, dissection was under increasing pressure, it was still widely felt to be an appropriate punishment for murder, as Parliament's refusal to repeal the relevant clause of the Murder Act in 1828 and 1829 indicates.

\section{The 1828-1829 Debates and the Reluctance to End Post-execution Punishment}

The story of the surgeons' campaign to find alternative sources of cadavers, which gained momentum in the 1820s and finally gave them access to the bodies of the poor through the Anatomy Act of 1832, has already been analysed in detail, as has the long-term impact of the that Act. ${ }^{231}$ However, the element within the surgeons' campaign that is most relevant to the history of post-execution punishment-their demand that dissection no longer be used as a penal strategy — has not been fully analysed and this will be the main focus here. Although the surgeons had only played a relatively minor part in the eighteenth-century debates about the use of dissection as a sentencing option, in the early-nineteenth century they became increasingly convinced that their penal role had become highly counterproductive, and that it was therefore time to put pressure on Parliament to repeal the relevant clauses of the Murder Act and thereby put an end to dissection as a post-execution punishment. By the mid-1820s this had become an increasingly fixed element in their campaign. When they petitioned the Home Office in 1825 for permission to use the bodies of those who died in workhouses, infirmaries or prisons, they also requested the repeal of the law 'which gives over certain executed criminals for dissection' because this would remove 'the prejudices now existing against anatomy'. ${ }^{232}$ When Bentham, who played a seminal role in the campaign, wrote a draft 'Body Providing Bill' in 1826 he included a section repealing the relevant parts of the Murder Act and in 1827 The Lancet, having previously published an article proposing the repeal of 'those barbarous laws ... which consign criminals to dissection', reported that it 'had been given to understand, from undoubted authority, that it (the repeal) will be 
accomplished by Mr. Peel during the next session of Parliament'. ${ }^{233}$ It was not accomplished that year, and Peel's attitude at this point appears to have been much less positive than The Lancet's report implied, but Lansdowne, who (due to a temporary change of government) replaced Peel at the Home Office from July 1827 to January 1828, was clearly committed to repeal by 1828 .

Richardson did not analyse this aspect of the period leading up to Warburton's request for a Parliamentary Select Committee on 22nd April 1828, but between mid-March 1828 and 22nd April Lansdowne made a concerted attempt to obtain repeal. ${ }^{234}$ On 14th March, after presenting a petition sent to Parliament by the surgeons of Worcester asking for a new means of obtaining bodies for dissection, Lansdowne announced that 'he thought the best way to proceed, in the first place, would be to repeal the existing law ${ }^{, 235}$ and he put that plan into action two weeks later at the end of parliamentary discussions on a different bill that eventually became the 1828 'Offences against the Person Act'. That legislation, thereafter known as Lansdowne's Act, was mainly a consolidating measure covering many forms of violence including murder, although it also introduced new powers enabling the summary courts to punish offenders for assault. ${ }^{236}$ However, on 28th March, when the bill was in the committee stage, Lansdowne brought forward a late amendment proposing that the penal dissection clause of the Murder Act be left out when it was consolidated within the new Act. ${ }^{237}$ The precise conjunction of events that brought this about is difficult to reconstruct and it is interesting that Peel, who was now back in post as Home Secretary, did not speak in the debate. However, Lansdowne openly declared that he was proposing the amendment because 'he had had some correspondence with medical men' who were concerned about 'the stigma' that 'condemning criminals to dissection' created, ${ }^{238}$ and it seems clear that by March 1828 a large group of surgeons and Benthamites, with the help of the ex-Home Secretary, were mounting a concerted parliamentary attack on penal dissection.

This was no easy task. At the third reading of the Offences Against the Person Bill in the Lords on 15th April Lansdowne's amendment ran into concerted opposition from two very different quarters. Both the future Whig Prime Minister, Earl Grey (a long-term supporter of Romilly's campaign to repeal the capital code), and the high Tory Lord Chief Justice, Lord Tenterden (who like most of the judges was an avowed opponent of criminal justice reform), began by expressing doubts about whether penal dissection really did create any stigma against anatomy. Following this, 
Tenterden's main argument was that any amendment 'which might tend ... to make men feel less terror at the punishment for murder and might lessen their motives for abstaining from ... such a crime' should not be considered, even if it only prevented one murder every 20 years. ${ }^{239}$ Grey based his much more detailed critique mainly on the two themes we have already identified in the early-nineteenth-century discourse-differentiation and deterrence. 'The punishment of death was unhappily extended to many offences of an inferior nature to ...murder', he argued, ${ }^{240}$ ' $[\mathrm{t}] \mathrm{hat}$ being so ... the distinction now attached to ... murder ... that the body of the murderer was given up for dissection', should be preserved. ${ }^{241} \mathrm{He}$ opposed the extension of the punishment of dissection to other crimes and, 'as the converse of that position', rejected Lansdowne's attempt to end the differentiation between murder and 'minor offences'. Grey then went on to discuss the deterrent value of dissection. Although he admitted that 'no effect would be produced on the individual' who had made up his mind to commit murder, Grey still contended that 'the additional punishment of dissection' created 'a salutary terror' in the community and maintained 'a horror of the crime of murder' within it. ${ }^{242}$ This argument was not entirely consistent. As the Morning Chronicle pointed out, 'he wishes to terrify those who are not likely to commit murder by means which will have no effect in terrifying those likely to commit murder'. ${ }^{243}$ Despite these criticisms, and Lansdowne's concluding speech stressing that it could not be idle theory' that condemning murderers to dissection prevented people giving their bodies, on 15th April the House of Lords voted down Lansdowne's attempts to repeal this part of the Murder Act. ${ }^{244}$

However, the issue continued to attract the attention of Parliament. Petitions carried on pouring in from the surgeons of major cities such as Glasgow, Leeds and Liverpool, who not only asked for help in obtaining cadavers, but also referred to their fear of being prosecuted for possessing exhumed bodies as a result of a recent judgment at the Lancashire assizes, which had created new case law to that effect. ${ }^{245}$ Six days after Lansdowne's amendment was defeated, the current Home Secretary, Peel, after presenting a petition from the Royal College of Surgeons, informed the Commons that since Warburton would 'bring forward a motion for an inquiry into the subject' the following day, he would 'reserve any decisive opinion' on the matter till he had heard Warburton speak. ${ }^{246}$ During the ensuing debate that day one high Tory MP suggested expanding the use of dissection to include suicides, an idea quickly refuted by Peel and by the radical MP Joseph Hume, who argued that 'making dissection at any time 
a penalty' could only increase the aversion of the community to it. ${ }^{247}$ The penal reformer, Sir James Mackintosh, having pointed out that 'the bodies of murderers proved a source of supply entirely unworthy of notice', and that no threat 'could add practically to the terror of the punishment of death' then ended the debate with a comment that had important long-term implications. The way to make a 'true distinction ... between the crime of murder and less heinous offences', he argued, 'would be to lighten ... the punishments inflicted for the latter ${ }^{248}$ _ an argument against the underlying logic of post-execution punishments for murder which as we will see, would become increasingly relevant as the reformers succeeded in obtaining the repeal of the capital statutes relating to most property offences in the early 1830s. Thus when, on the following day, Warburton asked the House to appoint a Select Committee on Anatomy, he did so in the context of an ongoing battle for the repeal of penal dissection, and of Lansdowne's failure, just one week earlier, to win that battle. Although the Committee focused most of its attention on creating alternative sources of supply to meet the surgeons' need for cadavers, it was also designed to be a major intervention in the debate on penal dissection.

Most of the witnesses appearing before the 1828 Parliamentary Select Committee on Anatomy, many of whom were handpicked 'first degree Benthamites', overwhelmingly endorsed the view that the dissection clauses of the Murder Act should be immediately repealed. ${ }^{249}$ With monotonous regularity more than fifteen witnesses responded to leading questions such as 'do you concur in the opinion, that the giving up the bodies of murderers for dissection tends to aggravate ... public feeling against dissection' by talking about its injurious effects and recommending repeal. For example, the President of the Royal College of Surgeons, Sir Astley Cooper, argued that 'the dissection of murderers' was 'the greatest stigma on anatomy ... and extremely injurious to science', while another witness pointed out that 'to make an anatomist the executioner of the laws, must ... create an odium against us' ${ }^{250}$ Although one or two mildly dissenting voices were allowed, ${ }^{251}$ those who guided the membership and terms of reference of the 1828 Committee, and the questions it asked, were highly successful in marshalling evidence recommending that dissection needed to be immediately abandoned as a penal option. The committee's report, offered to Parliament in 1829, clearly reflected this. It recommended repealing the clauses of the Murder Act directing 'that the bodies of murderers be ... anatomized' because, 'by attaching to dissection the mark of ignominy', it increased 'the dislike of the public to 
anatomy'. ${ }^{252}$ Those who orchestrated the committee were well aware that they had to tread carefully on this issue and in the report's conclusion they professed themselves 'very unwilling to interfere with any penal enactment which might ... prevent the commission of atrocious crimes'. However, they argued strongly that 'as it can be reasonably doubted whether the dread of dissection can be reckoned amongst the obstacles to the perpetration of such crimes and as ...the clause in question must create a strong and mischievous prejudice against the practice of anatomy' it should therefore be repealed. ${ }^{253}$

Given that the Benthamites behind the 1829 Anatomy bill were clearly committed to ending penal dissection, and had organized a chorus of witnesses to advocate the repeal of the Murder Act's key clauses, it is extremely surprising that the Bill introduced into Parliament by Warburton in March 1829 did not included any attempt to repeal those clauses. Richardson has suggested that the repeal clause was mysteriously dropped from the bill for tactical reasons. 'The Royal College, of which Cooper was president, wanted to preserve its privileged right to corpses', she suggested, but Warburton and his supporters 'were opposed to ceding this power to the Royal College and probably thought that the omission of Bentham's clause repealing the dissection of murderers a small price to pay to pacify the College'. ${ }^{254}$ However, there are a number of problems with this explanation, not the least being Cooper's direct advocacy of repeal before the 1828 committee. While Richardson may conceivably be correct that internal politics between different surgical interest groups played a role in the dropping of the repeal clause, a closer analysis suggests that it was the potential opposition of key parliamentary figures, who wanted to preserve dissection because of its value as a post-execution punishment, which played a central role in Warburton's 1829 decision.

Not all members of Parliament wanted to continue with the use of dissection as a punishment for murder. Lansdowne could still be relied on to advocate repeal in the Lords and when the 1829 Bill was debated in the Commons in May the Tory MP Sir Robert Inglis also made a long speech demanding the end of penal dissection. It was vital, he argued, to make a distinction between 'the man who dies on the scaffold' and the poor man dying in a workhouse. 'For my own part', he observed, 'I have no wish to alter the law relative to the bodies of murderers; but if this bill is to pass, I think that law ought to continue no longer'. You therefore need, he told the advocates of the bill, to 'take your choice between criminals and the friendless', and since only eleven murderers' bodies were available in the 
year 1827 (and only seventy were executed for any offence) choosing the criminal option would 'not furnish one-tenth of the subjects necessary for science'. ${ }^{255}$ This argument made very little headway. Even before Inglis proposed it in open debate, it 'had been already discussed in the committee on the bill, and there rejected', and Inglis's attempt to revive it was voted down by a huge majority of forty votes to eight. ${ }^{256}$ However, Warburton's immediate response to Inglis's reintroduction of the repeal issue into the 1829 debate offers important clues about why he chose not to include a repeal clause in the original 1829 Bill.

When he had first introduced the Bill, Warburton reminded the House, he felt 'the evidence was in favour of the repeal of this clause' but 'after conferring with ... those Honourable Gentlemen on whom the fate of the bill depended' he was convinced that for the bill to be successful in this and another place (i.e. the House of Lords), it must contain no such provision'. ${ }^{257}$ The resounding vote against Inglis's proposed amendment in the Commons (which then passed the bill without it) and the fact that the bill was then rejected by the Lords, where it failed to get support from key figures such as the Chief Justice, Earl Grey and the Archbishop of Canterbury, suggests that those Warburton conferred with were absolutely right. $^{258}$ Moreover, although Peel deliberately kept a low profile on the issue, he was also against repeal. In the May 1829 one of the MPs who responded to Inglis's proposal expressed his regret that Peel had not bothered to attend the debate 'to state the reasons which induced him, as well as the committee', to reject it, and as current Home Secretary Peel he was almost certainly one of the 'Honourable Gentlemen' who advised Warburton to drop the repeal clause. Thus even at this point, after more than three-quarters of a century as a penal sanction, and after the almost complete disappearance of hanging in chains, the use of dissection as a post-execution punishment still had widespread support in Parliament and in government circles. However, those wishing to repeal the relevant clause of the Murder Act were not about to give up. Nor were the supporters of the much broader Anatomy Bill. Even though he could see that the 1829 Lords debate was going against him, Lansdowne still used that debate as an opportunity to suggest that 'when another measure should be brought forward, he would certainly propose that the law directing that the bodies of malefactors should be given over for dissection ... be repealed' ${ }^{259}$ At the close of the parliamentary session three weeks later, Warburton duly gave notice that he intended to bring in another bill in the next session ${ }^{260}$ and although the political turmoil of the following year caused a temporary 
delay, the bill that became the 1832 Anatomy Act was eventually introduced to parliament at the end of $1831 .^{261}$

\section{The Final Repeal of the Dissection Clause of THE Murder ACT, 1829-1832}

Richardson has already provided a good overall analysis of the complex and multi-stranded debate that developed between the failure of the 1829 bill and the passing of the 1832 Anatomy Act. Warburton and his Benthamite colleagues had always intended 'to single out the very poor for dissection' and by a variety of linguistic dishonesties and parliamentary malpractices, and by using the growing outcry against the resurrection men and the sense of urgency created by the prosecution of 'the London Burkers', they achieved this aim in $1832 .^{262}$ In the process they put an end to penal dissection, Warburton's second anatomy bill specifically enacting that 'so much of the Murder Act as directs that the bodies of murderers may be dissected', be repealed. ${ }^{263}$ Between 1829 and the introduction of the second bill to Parliament in December 1831 the surgeons' concern to separate the dissection process from any association with executions and punishment grew ever stronger. In 1829 a pamphlet on obtaining bodies for anatomy, having pointed out that the dissection of murderers was a major cause of 'public prejudice', argued that the legislature's first step should be the repeal of the Murder Act. ${ }^{264}$ In the following year The Lancet not only pointed out that penal dissection lowered the social standing of the surgeons' profession, but also questioned, along with other contributors to the debate, the surgeons' role as 'finishers of the law'-a role in ensuring medical death that Hurren has shown was much more frequently exercised than most contemporaries realized. ${ }^{265}$ Other writers pointed out more pragmatically that patients dying in hospital expressed strong feelings against being dissected because it would be treating them like murderers, and that 'brutal and disgusting exhibitions of the murderer's body' were 'inculcating a horror of anatomy'. ${ }^{266}$ In 1830 a writer in the Quarterly Review went further. Angry at the 'unfortunate association produced by penal dissection', and worried that 'several of those who have spoken in Parliament on the subject have declared that they will never consent to its abolition', he suggested a strike. After pointing out that the law could not legally compel a surgeon to perform a penal dissection (as the case law we have already discussed had long established), he suggested that 
the surgeons simply 'decline a task that requires them to become post-mortem executioners' and 'let Jack Ketch ... take to himself the office of anatomical executioner'. ${ }^{267}$

Although this view that penal dissection was a major source of 'public repugnance ${ }^{268}$ was powerfully advocated by Warburton and his colleagues between 1829 and 1831 (as it had already been before the 1828 Select Committee), there remained significant dissenting voices who not only opposed the curbing of penal dissection but also advocated that its use be extended to cover other types of offender. In 1829 Professor Guthrie, a prominent member of the Royal College of Surgeons, argued that the operation of the Murder Act did not, in itself, create any adverse feelings about dissection, and went on to suggest that the bodies of all executed offenders and of all those who died whilst imprisoned for criminal offences should be given to the surgeons. ${ }^{269}$ In 1831, an article in the monthly magazine, The Moral Reformer, also suggested that the bodies of those found guilty of 'other crimes as well as murder' and those who might be given a life sentence as 'a substitute for the punishment of death' should be sent for dissection. ${ }^{270}$ In February 1832 a petition from the inhabitants of Blackburn suggested giving over, for dissection, the bodies of murderers, suicides and 'all persons who die by the scandalous practice of dueling', and the petition sent in by the Mechanics of Lambeth was even more radical, suggesting that-as well as suicides, duelists and convicted felons-all those 'in receipt of unmerited pensions', all surgical practitioners and all the MPs who 'voted for Mr. Warburton's Bill' should also have their bodies sent for dissection. ${ }^{271}$ Whilst this suggestion was clearly regarded as too extreme, the expansion of penal dissection to include a broader range of offenders continued to be put forward during the debate on the Second Anatomy Bill, which began in December 1831. The Bill's main opponent in the Commons, the radical reformer Henry Hunt, having criticized 'the insufferable doctrine' that the poor were to be dissected because of their poverty while murderers and thieves would 'escape this process', suggested on two separate occasions that all capital convicts, suicides and 'persons dying after a conviction for felony' should be given to the surgeons. ${ }^{272}$ In the Lords a very similar position was taken up by a recently retired judge, Lord Wynford, an opponent of parliamentary reform, who not only demanded that 'the law which gave the bodies of murderers up for dissection should not be altered', but also argued that 'those convicted of felony, whether executed or dying in prison' and 'those who destroyed themselves' should be ordered for dissection. ${ }^{273}$ 
This continued advocacy of the large-scale expansion of penal dissection on the very eve of the passing of the Anatomy Act, which would end its use even for murder, indicates how deeply attached judges like Wynford still were to the use of post-execution punishment, but it may also be partly explained (in Hunt's case at least) by the difficult strategic situation these opponents of the Act found themselves in. Both would have been well aware by this point that they had little chance of success. Every time Hunt brought an amendment, and at every stage of the bill's journey through the Commons, Warburton's supporters defeated him by massive majorities. Things were a little better in the Lords, but Wynford also sounded resigned, observing at one point that 'he should divide the House, even if he had to go to the bar alone'. ${ }^{274}$ To prevent the poor becoming the main targets of the anatomists the bill's opponents had to come up with a viable alternative, and to do so they drew on a long tradition that stretched back to Wilberforce's 1786 bill and beyond, and involved massively expanding the types of offenders to be sentenced to dissection. This Wynford pointed out, would provide 'a sufficient supply of subjects for the study of anatomy', without 'the necessity of passing the present invidious measure which ... left the poor and miserable unprotected'. Wynford could, and did, also claim that his experience as a judge had proved to him that dissection was 'a useful and effective punishment' and although Hunt had no such experience, and came from the opposite end of the political spectrum, he seems to have thought it expedient to take the same view.

However, the idea of expanding penal dissection in this way received very little support in the parliamentary debates of 1831-1832. One MP spoke briefly in favour of giving the 'dead bodies of all criminals' to the surgeons $^{275}$ and another highly eccentric Tory MP, Colonel Sibthorpe, requested that 'those most rascally of all criminals, horse-stealers', should be dissected along with murderers. ${ }^{276}$ On the other hand a chorus of voices demanded that the House go the other way and end penal dissection completely. Sir Robert Inglis, who had already attempted to get a repealing amendment through in 1829, made several speeches to that effect. ${ }^{277}$ The Cornish MP Sir Richard Vyvyan argued that repealing the Murder Act was 'absolutely necessary' and other MPs made similar speeches. ${ }^{278}$ When Hunt tried a new tactic and proposed an amendment designed simply to 'leave the Judges the power of ordering murderers ... for dissection' he got nowhere. He was the only MP out of fifty who voted in favour. ${ }^{279}$ In the Lords, where the judges and particularly the leading judge-the Lord Chancellor-traditionally had a major say when any changes in penal policy 
were proposed, the argument followed a rather different path. During the debate on the second reading in June 1832, just after Wynford had suggested greatly expanding the types of offender subjected to dissection, the Lord Chancellor quietly refuted his argument by reasserting the need for differentiation between different offences. 'As to giving up the bodies of all persons dying under sentence of felony', he observed, 'that might enhance the penalty on some felonies, but would lower it in the case of murder' and changing the current situation in which 'dissection was ... only attached to the highest species of crime' would in his view be 'extremely prejudicial'. ${ }^{280}$ $\mathrm{He}$ did not, however, commit himself on the more limited question that the debate now focused on-should the relevant clause of the Murder Act be repealed? While observing that 'some doubted' that 'dissection ought to be made the sentence for murder', the Lord Chancellor very pointedly avoided stating that he agreed with that view, while at the same time making it clear that he was not happy with 'every provision of the bill'. ${ }^{281}$

This may well have encouraged Wynford to follow Hunt's example and focus on preserving the penal dissection of murderers alone. During the bill's third reading in the Lords, Wynford proposed that the clause repealing the Murder Act be deleted because 'it was well known that the fear of dissection' was a powerful deterrent, and his proposal may well have had significant support. Lord Kenyon, son of the famous Lord Chancellor who had preceded Lord Eldon, was recorded as concurring in 'the learned Lord's view of the subject' and the Lord Chancellor, having made some vague, but probably supportive, remarks a month earlier, certainly did not speak against it. ${ }^{282}$ Wynford might also have expected support from Earl Grey, who had opposed repeal in 1828 , and in his speech in the debate Grey did indeed admit 'the justice of the learned Lord's remarks' before observing that 'he should be sorry to do away with any portion of the effective punishment of murder, without providing an adequate substitute'. ${ }^{283}$ However, it soon became clear that Grey was looking for a compromise. He was prepared to end penal dissection but did not think it was possible to do so without keeping some form of post-execution punishment as a means of preserving differences in sentencing between murder and lesser offences. 'Unfortunately', Grey observed, since penal dissection created so many prejudices against anatomy 'it was thought advantageous to do away with the dissection of murderers'. He therefore proposed, 'in order to distinguish murder from other crimes', and avoid 'lessening the moral horror of the offence' a new clause which (after some honing down in discussion with other members) was designed to enact that 'the bodies 
of all prisoners convicted of murder should either be hung in chains, or buried under the gallows on which they had been executed, or within the precincts of the prison' where they had been confined. ${ }^{284}$ Although it remains unclear whether Wynford was entirely happy with this, Grey was Prime Minister by this point and therefore in an ideal position to broker a compromise, and at the end of the debate Hansard simply records 'clause agreed to, and the bill read a third time and passed'. ${ }^{285}$

The ending of dissection as a post-execution punishment had not gone uncontested, and, even at the death, the idea that the use of penal dissection should be expanded to all criminal offenders, and also to suicides, was still being seriously debated. The House of Lords, unable, it seems, to give up the idea that murder should be punished more severely than other capital offences, had compromised by introducing a new, if very private, form of post-execution punishment-burial in the prison grounds. (The less practical option of burying the corpse under the gallows was left largely unused.) At the same time they had reasserted the judges' right to sentence murderers to hanging in chains - an option that the Anatomy Act had not in any case aimed to remove. The judges who were now deprived of the ability to use their preferred post-execution option-dissection under the Murder Act-could still order that an offender's corpse be hung in chains. However, when two of them did just that almost immediately after the passing of the Anatomy Act, a massive reaction against the use of gibbeting quickly extinguished this final vestige of the era of public post-execution punishments in England.

\section{Brief Revival and Rapid Repeal: The Abolition of Hanging in Chains}

Hanging in chains was rarely mentioned during the 1828-1832 debates. During the second reading of the 1832 Anatomy Bill Hunt briefly referred to the fact that it would 'restore the old brutal system of hanging in chains', and in opposing the third reading another MP announced 'he should never consent' to the barbarous idea of reviving 'the custom of hanging in chains'. ${ }^{286}$ Although Earl Grey eventually agreed to its inclusion in his compromise amendment, he does not appear to have been particularly positive about it either. Two months after the 1832 debate the Morning Herald reported that, in his desire to appease Lord Wynford, Grey had only initially proposed 'a clause providing that the bodies of murderers should 
be buried beneath the gallows ... or within the precincts of the prison'. This does not seem to have been enough, however, and subsequently, the paper reported, he 'was weak enough to be induced' to include hanging in chains as an option. ${ }^{287}$ The pressures Grey was under at this point remain unclear, but when he was a circuit judge Lord Wynford had been the last member of the assizes bench to sentence an offender to hanging in chains only 5 years before 1832 , and it is quite likely therefore that Wynford persuaded Grey to include this punishment in his amendment. ${ }^{288}$

Since 'in the two first instances of conviction for murder which followed the passing of the Act' two of the current circuit judges immediately resorted to the use of hanging in chains, it is possible that Wynford was not alone in his advocacy of gibbeting. ${ }^{289}$ However, Judge Parke, who passed the first of these sentences on the remote Northern Circuit only seven days after the Act received the royal assent, may have done so mainly because he was unsure how to proceed. Since dissection was now abolished, he observed when addressing the convict, William Jobling, 'in order that he should not have an erroneous sentence, by directing the body of the prisoner to be dissected, he should direct that it should be hung in chains'. ${ }^{290}$ However, by the time the second gibbeting sentence was passed two weeks after the 1832 Act had received the royal assent, the new law had been fully communicated to all the circuit judges and was being formally announced by them at the commencement of each assizes. ${ }^{291}$ The second assize judge's decision to gibbet the Leicestershire murderer James Cook was not therefore a simple matter of avoiding error. Instead it was clearly a deliberately punitive response, since the judge referred in passing sentence, to 'the atrocious circumstances' of the case. ${ }^{292}$ However, the judges would never again be allowed to respond to particularly 'atrocious' cases such as this (Cook had cut up and burnt the body of his victim) by punishing the criminal's corpse in any way apart from burial in the prison grounds. $^{293}$

These two gibbetings in early August 1832 attracted huge crowds and in Leicester a fairground atmosphere quickly developed around Cook's suspended body. However, neither corpse stayed long on its gibbet. Jobling's body was quickly rescued by his fellow colliers and buried in a local churchyard. ${ }^{294}$ Cook's carcass was taken down after three days by order of the Home Secretary-a decision much praised in the press, which had been highly critical of 'the disgraceful revival' of this 'brutal antiquated custom'. ${ }^{295}$ The Royal Cornwall Gazette, for example, rejoiced at the remitting of this part of the sentence after three days. 'Even this tardy 
repeal', it reported, 'is creditable to the feeling of the King'. ${ }^{296}$ In the months that followed this 'practice of barbarous origin, which the progress of civilization had exploded' was widely criticized on a number of grounds. ${ }^{297}$ It tended 'to brutalize the populace, not to improve or instruct them', the English Chronicle observed. ${ }^{298}$ The Morning Herald agreed. 'The gibbet', it observed in August 1832, 'never reforms, but always brutalizes-just as breaking on the wheel and exposing the body afterwards, under the old regime of France, only tended, by hardening the feelings of the spectators' to increase murder rates. ${ }^{299}$ Hanging in chains was also regarded as inefficient, since 'the exhibition of the body shocked those only on whom it was never meant to exercise as a warning, and became nothing but an object of idle curiosity to those to whom it was meant to be an awful example'. ${ }^{300}$ Even more important, perhaps, it delegitimized the law. 'We would have the laws reasonable, temperate, and decent, that they may not be despised or insulted' the Morning Herald commented a few days after Cook's gibbeting. 'The revival of the odious practice of gibbeting which had been banished by the progress of civilized habits', it later added, 'was a great disgrace to the legislature of England in the nineteenth century'. ${ }^{301}$ More pragmatic considerations were also important. When speculating about why the government had taken down Cook's corpse after only three days, the local paper pointed out that should murders be as frequent during the next 12 years as they had been in the last 12 years 'the county would be frightfully studded with such exhibitions'. ${ }^{302}$

It is difficult to find any contemporary commentators who responded to these criticisms by arguing in favour of hanging in chains, and it is not therefore surprising that when the penal reformer William Ewart introduced a bill into Parliament 'To Abolish the Practice of Hanging the Bodies of Criminals in Chains' it went through the Commons unopposed. ${ }^{303}$ Ewart did not even bother to make a case for abolition. It was unnecessary, he argued, since the government had indicated it was 'willing to abolish this odious practice'. ${ }^{304}$ The bill had an equally easy passage through the House of Lords, where the liberal reformer, Lord Suffield said 'he was at a loss to find any reason for continuing such a practice'. Burying the offenders' bodies within prison precincts was, he argued, carrying 'vengeance' far enough. ${ }^{305}$ After the committee stage in the Lords, the Earl of Shaftesbury reported that no amendments had been thought necessary, and a day later the bill passed its third reading without further debate. ${ }^{306}$ 
Given that only 2 years earlier the Lords had presented enough opposition to the ending of penal dissection to force Grey into producing a compromise amendment involving the continuance of hanging in chains, the 1834 bill's easy passage through the upper house may seem surprising. However, between 1832 and the passing of Ewart's bill in July 1834 a vital change had taken place. Under Earl Grey's leadership the reforming Whig government had not only passed the First Reform Act and abolished slavery, but had also begun to repeal many of the statutes that had made a wide variety of property crimes into capital offences. Coinage offences and nearly all forms of forgery were made non-capital in 1832, and in the same year Ewart's bill making horse, sheep and cattle stealing, and larceny in the dwelling house non-capital had also passed, despite strong opposition from Peel in the Commons and from the Lord Chief Justice and Lord Wynford in the Lords, where Wynford managed to force through another short-lived but harsh amendment. ${ }^{307}$ The repeal of the Bloody Code was still going on in 1834, with a leading role being played by the same two men who were pushing for the end of hanging in chains. Two weeks after introducing his anti-gibbeting bill, Ewart asked the Commons for leave to bring in another 'Capital Punishment Bill' abolishing the death sentence for letter-stealing, burglary and returning from transportation, and two weeks after Suffield introduced the anti-gibbeting bill in the Lords he was supporting the passage of the same 'Capital Punishment Bill' through the upper house. ${ }^{308}$

As it became clear that almost all property offences would soon be non-capital but that murderers would still be sent to the gallows, the core argument of those who opposed the ending of penal dissection (and the few who still advocated hanging in chains) — that it was necessary to impose a more severe form of capital punishment on murderers than on mere property thieves-was completely undermined. In 1834 an MP arguing that robbery should no longer be a capital crime adapted the familiar eighteenth-century argument-'that, by putting the punishment of robbery on a rank with that for murder, murder was brought down to the rank of robbery ${ }^{309}$ - to this new context. Differentiation could now be achieved, he and others argued, not by adding extra post-execution dimensions to the punishment of murder but by removing the death penalty from other lesser crimes. This idea had already been floated before the large-scale repeal of the Bloody Code had begun. In 1829, for example, one commentator argued that the dissection of murderers should only be discontinued once the punishment of death was attached to 
murder alone, and by 1832 the Whig Lord Chancellor, Henry Brougham, was arguing along similar lines. ${ }^{310}$ Only 6 years before the 1834 Act Mackintosh's rejection of penal dissection on the grounds that the best way to distinguish 'between murder and less heinous offences would be to lighten the punishments inflicted on the latter' had seemed extremely idealistic. ${ }^{311}$ However, as the Whigs reversed the Tory policy of consolidation and very limited actual reform, and began the wholesale repeal of almost every capital statute that could result in the sentencing of a significant number of property offenders to the gallows, the death sentence itself had indeed become the key method of creating differentiation in penal policy. The complete lack of opposition to the ending of public post-execution punishment in 1834 and the obvious willingness of the House of Commons to end penal dissection in 1832 needs to be seen in this context, as does Grey's change of heart over penal dissection. In 1828 and 1829 he had been one of the main advocates of retaining penal dissection. However, by July 1832, when he brokered the compromise in the Lords that put an end to penal dissection, many key property offences had already been, or were about to be, made non-capital. ${ }^{312}$ Given that even those who opposed the repeal of the Murder Act were, by this point, admitting that penal dissection did not usually deter offenders from committing murder, the only effective rationale for that Act was the need to differentiate the punishment of murder from that for other capital offences. As it became clear in the new political situation of the early 1830s that differentiation could now be achieved by leaving murder, and one or two other particularly heinous offences, as the only crimes that would be punished by death, the main argument in favour of retaining any major form of post-execution punishment was decisively undermined.

The surgeons' very urgent need to find new sources of supply, the growing public opposition to the activities of the resurrection men, and the panic created in the late 1820 s and early 1830 s by 'Burkophobia' undoubtedly provided the short-term catalyst for the ending of penal dissection. However, by the early 1830s the surgeons were pushing at an open door. The formal post-execution regime created by the Murder Act lasted for as long as it was thought to be necessary and useful by the judges and their parliamentary supporters. When, in the early 1830s, it was clearly becoming redundant because the repeal of the Bloody Code had created a new means of achieving penal differentiation, public post-execution punishment was abandoned. The passing of the 1832 Anatomy Act may well have reflected the increasing power of the anatomists as a parliamentary 
lobby, and the discretion thesurgeons had been given by the Murder Act meant that a surgeons' strike was a real possibility, or at least a useful bargaining tool. However, ending the use of dissection as a penal strategy proved beyond the powers of Warburton and his supporters in 1829, just as their attempt to add it to the 1828 Act had done. They received no visible support from Peel, and although they got temporary backing from Lansdowne they failed to persuade the key Whig leader Earl Grey to back them. In 1829 they were told quite categorically that any Anatomy Bill with such a clause in it would fail, and they didn't even try to get the penal dissection clause past the judges in the Lords. Nor was this a new situation. At various intervals throughout the Murder Act period between 1752 and 1832, and especially in 1786 and 1796 , they tried to get the principle of penal dissection extended to a range of other offences, with the aim of turning the almost insignificant trickle of cadavers made available by the Murder Act into an important supply stream. In 1786 they even got limited government backing, which enabled them to get the bill through the Commons. However, the House of Lords (and the judges that formed such a powerful pressure group within it) consistently rejected those attempts for the same reason that they later rejected the repeal of penal dissection - that it would undermine the principle of differentiation in punishment. Although the extension of penal dissection to other types of offender, and even to all felons dying in prison, continued to be advocated in the 1828-1832 debates, this argument was no more successful than it had been in 1786 and 1796. By this point the surgeon's had, in any case, focused on a much more convenient and easy target-the destitute and friendless poor-but when it came to expanding the categories of offenders covered by the Murder Act the Lords remained as intractable as ever.

Seen in this light, it seems clear that from 1752 until the radical penal reforms of the 1830s the ways post-execution punishment was used in England were almost entirely determined by criminal justice priorities. The Murder Act never gave the surgeons a significant supply of cadavers. Indeed, if Devereaux is correct, the number of criminal corpses given to the London surgeons may even have declined as a result of the Act. ${ }^{313}$ When the provincial surgeons pressed for extension in 1786 they were vetoed by the Law Lords, and the surgeons' victory in 1832 was also more apparent than real. Even after producing a large array of witnesses demanding repeal before a carefully selected parliamentary committee in 1828, they faced implacable opposition to the repeal of penal dissection and did not even attempt to include it in the first anatomy bill. Only in 1832, after the repeal 
of the Bloody Code had begun and the underlying logic of post-execution punishment was being fundamentally undermined, did the surgeons finally achieve repeal of the dissection clauses of the Murder Act, which could only come once the penal foundations that held those clauses in place had begun to crumble.

\section{Notes}

1. S. Devereaux, 'England's "Bloody Code" in Crisis and Transition: Executions at the Old Bailey, 1760-1837' Journal of the Canadian Historical Association, 24 (2013) p. 77.

2. The Times, 31 January 1800; Almost every eighteenth-century legal commentator blamed the uncertainty of English law on the confusions produced by poorly expressed statute law. D. Lieberman, The Province of Legislation Determined. Legal Theory in Eighteenth-Century Britain (Cambridge, 1989) p. 237.

3. P. King, Crime and Law in England 1750-1840: Remaking Justice from the Margins (Cambridge, 2006) pp. 22-25.

4. These issues are recorded in the Judges 'Resolution on the Manner of Sentencing under the Murder Act', 7 May 1752 in the National Army Museum Archives, (hitherto NAMA) ref 6510-146(2) -24.

5. Ibid. and W. Hawkins, A Treatise of the Pleas of the Crown (London, sixth edition, 1787) pp. 659-661; M. Foster, A Report of Some Proceeding for the Trial of the Rebels ... and of other Crown Cases (Dublin 1791) p. 107. The Murder Act had stipulated that the convicted murderer be hanged within two or three days of sentencing and this was the part deemed to apply also to women.

6. 'Judges' Resolution on the Applicability of the Murder Act to the Case of Earl Ferrers', 23 April 1760 in the NAMA, ref 6510-146(2) -30.

7. 25 Geo II. c. 37-An Act for Better Preventing the Horrid Crime of Murder.

8. Ibid. In any other county the body was to be delivered to 'such surgeon as such judge ... shall direct'.

9. Ibid.

10. R. Richardson, Death, Dissection and the Destitute (London, 1989) p. 37.

11. J. Sawday, The Body Emblazoned; Dissection and the Human Body in Renaissance Culture (London, 1995) p. 54.

12. E. Hurren, Dissecting the Criminal Corpse; Post-execution Punishment in Early Modern England, from the Murder Act (1752) to the Anatomy Act (1832) (Basingstoke, 2016) pp. 7-8.

13. Ibid., p. 7.

14. Ibid., pp. 6-9. 
15. Ibid., p. 10.

16. Ibid., p. 23.

17. Ibid., pp. 22-23, 38-39.

18. Ibid., pp. 22-23.

19. Ibid., p. 155 and 191.

20. Ibid., p. 39.

21. Public Ledger, 6 May 1760.

22. Hurren, Dissecting, pp. 157-158.

23. Described in C. Wall, The History of the Surgeons' Company 1745-1800 (London, 1937) p. 103.

24. Ibid.

25. Hurren, Dissecting, pp. 157-160. Publicly displaying the corpse was criticised severely in the London Evening Post, 28 March 1760 for debasing his rank and for making a spectacle 'for gratifying the insolence of the Mob'.

26. D. Gray and P. King 'The Killing of Constable Linnell: The Impact of Xenophobia and of Elite Connections on Eighteenth-Century Justice' Family and Community History, 16 (2013).

27. Anon, An Account of the Trial and Conduct of John Webborn (Place of publication unknown, 1799).

28. Bath Herald, 15 August 1795.

29. St James Chronicle and British Evening Post, 18 March 1762.

30. TNA, E389/250/79, 245/186, 242/380 and 383.

31. Hurren, Dissecting, pp. 125-126; R. Ward, 'The Criminal Corpse, Anatomists, and the Criminal Law: Parliamentary Attempts to Extend the Dissection of Offenders in Late Eighteenth-Century England' Journal of British Studies, 54 (2015) pp. 76-79.

32. Ward, 'The Criminal Corpse', p. 77.

33. Hurren, Dissecting, pp. 155-156.

34. Ordinary's Account, 3rd October 1759, (OA17591003 www.oldbaileyonline.org version 6.0., 14 September 2012).

35. Ibid.

36. Royal College of Surgeons, cos/1/1 min book of the Court of Assistants Vol. 1 1745-1800 108/4032-3 indicates the skeletons in the theatre were ordered to be cleaned and repaired. 108/4095-4113 Triennial Report, vol. 1 indicates the disposal of bodies of dissected murderers was left to the discretion of the master and wardens.

37. In the famous Burke case the Scottish judge observed in giving sentence. 'I trust that if it is ever customary to preserve skeletons, yours will be preserved'. W. Roughead, Burke and Hare (London, 1921).

38. Public Advertiser, 16 September 1767. For a contemporary drawing of the corpse in its niche-D. Rumbelow, The Triple Tree, (London, 1982) p. 181 . 
39. The newspapers gave considerable publicity to Weil being hung up in Surgeons' Hall, London Evening Post, 10 December 1771.

40. Annual Register, 1771, pp. 161 and 210-215.

41. Public Advertiser, 14 December 1771.

42. London Daily Advertiser, 3 July 1752; Hurren, Dissecting, pp. 136-138.

43. P. Beirne, Hogarth's Art of Animal Cruelty. Satire, Suffering and Pictorial Propaganda (Basingstoke, 2015) pp. 71-72; R. Ward, Print Culture, Crime and Justice in Eighteenth-Century London (London, 2014) p. 196; T. Hitchcock and R. Shoemaker, Tales from the Hanging Court (London, 2006), pp. 255-269. Attitudes to highwaymen were changing, see A. McKenzie, Tyburn's Martyrs; Execution in England 1675-1775 (London, 2007), pp. 115-117: The Ordinary of Newgate's Account ... Of the 10 Malefactors Who were executed at Tyburn On Monday the 11th of February, 1751.The practice went back at least to the 1630s: Sawday, The Body, pp. 60-61.

44. Morning Post and Daily Advertiser, 17 January 1786. Hogan was described as 'black' or as 'a mulatto from the Madieras', P. King and J. Carter Wood 'Black People and the Criminal Justice System: Prejudice and Practice in Later Eighteenth- and Early Nineteenth-Century London' Historical Research, 88 (2015), pp. 116-117. The Public Advertiser did report on 20 January 1786 that 'a skeleton will be made of the Mulatto and placed in a niche in the hall by that of Mrs. Brownrig and other notorious offenders'.

45. Morning Post and Daily Advertiser, 18 December 1787.

46. They might also create skeletons from those deemed to have deformities e.g. the four-foot high murderer John Pycraft, Bury and Norwich Post, 25 August 1819 quoted in S. Tarlow, Hung in Chains: The Golden Ghoulish Age of the Gibbet in Britain (London, Palgrave, Forthcoming) p. 22.

47. For provincial convicts hung as skeletons see T. Lambley, Nottingham a Place of Execution from 1201 to 1928 (Wilford, 1981) p. 33, and two Suffolk examples, Bury and Norwich Post, 25 August 1819 and Lancaster Gazette and General Advertiser, 23 August 1828.

48. For a more general discussion of this process see King, Crime and Law, pp. 1-72.

49. Ward, Print Culture, pp. 200-201.

50. Ordinary's Account, 2 July 1752, (OAl7520702 www.oldbaileyonline.org version 6.0., 16 July 2013).

51. Old England or the National Gazette, 27 June 1752.

52. Ordinary's Account, 22 September 1752, (OA17520922 www.oldbaileyonline.org version 6.0., 16 July 2013).

53. Anon, A Warning Piece Against the Crime of Murder (London, 1752) p. iii. 
54. Gentleman's Magazine, 24 (1754) p. 506; W. Romaine, A Method for Preventing the Frequency of Robberies and Murders (London, 1754) p. 21.

55. Romaine, A Method, p. 3.

56. Gentleman's Magazine, 25 (1755) p. 295; London Magazine, (1755) pp. 159 and 211-212.

57. Ordinary's Account, 3rd October 1759, (OA17591003 www.oldbaileyonline.org version 6.0., 14 September 2012).

58. Harrop's Manchester Mercury, 3 April 1759.

59. W. Blackstone, Commentaries on the Laws of England (4 volumes, Oxford, 1765-1769) 4; W. Eden, Principles of Penal Law (London, 1771); H. Dagge, Considerations on Criminal Law (London, 1772); M. Dawes, An Essay on Crime and Punishments with a View of a Commentary Upon Beccaria, Rousseau, Voltaire, Montesquieu, Fielding and Blackstone (London, 1782); J. Howard, The State of the Prisons in England and Wales (Warrington, 1777); J. Hanway, The Defects of the Police ... with ... Proposals for Preventing Hanging and Transportation (London, 1775); R. McGowen, 'The Body and Punishment in Eighteenth-Century England' Journal of Modern History, 59 (1987) p. 667.

60. L. Radzinowicz, A History of English Criminal Law and its Administration from 1750, 1 (London, 1948) pp. 269-286, 301.

61. C. Beccaria, An Essay on Crimes and Punishments (translation Dublin, 1767) pp. 74, 79; Radzinowicz, A History, 1, pp. 270-271.

62. Beccaria, An Essay, p. 82.

63. Ibid., p. 75 .

64. Ibid., p. 76.

65. Ibid., p. 84.

66. Dawes, An Essay on Crime, pp. 54-55.

67. Bingley's Journal, 13 June 1772.

68. Ibid.

69. Ibid.

70. R. Shoemaker, 'Male Honour and the Decline of Public Violence in Eighteenth-Century London' Social History, 26 (2001), p. 193. However, murder rates declined most rapidly before the Murder Act.

71. Bingley's Journal, 13 June 1772.

72. Gentleman's Magazine, 41, (1771), p. 147; Radzinowicz, A History, 1, pp. 427-431.

73. London Magazine, 39, (1770) p. 448.

74. Gentleman's Magazine, 41, (1771), p. 147.

75. London Magazine, 39, (1770) p. 448.

76. Ibid., p. 447-448.

77. Gentleman's Magazine, 41, (1771), p. 147. 
78. Dawes, An Essay, pp. 54-55; D. Hay, 'The Laws of God and the Laws of Man: Lord Gordon and the Death Penalty' in J. Rule and R. Malcolmson (eds.), Protest and Survival: The Historical Experience (London, 1993) p. 65-66; W. Turner, 'Extract from an Essay on Crimes and Punishments' Memoirs of the Literary and Philosophical Society of Manchester, 2 March 1785 not only criticised the fact that 'crimes of different degrees of enormity' were 'punished equally' but also argued that even 'the punishment of murder by death' was 'a barbarous expedient'.

79. The Times, 21 November 1786, 5 May 1785, 20 October 1785, 5 November 1786.

80. Eden, Principles, p. 80.

81. St James Chronicle or British Evening Post, 24 May 1777.

82. General Evening Post, 9 April 1785.

83. The Times, 16 July 1786.

84. The Times, 20 January 1786; General Evening Post, 19 January 1786.

85. Lady's Magazine, May 1782.

86. Blackstone, Commentaries, 4, (12th edition, London, 1795) p. 201.

87. London Magazine, 38, (1769) p. 384.

88. Gazetteer and New Daily Advertiser, 26 July 1766.

89. York Chronicle, 26 March 1773.

90. S. Devereaux, 'Recasting the Theatre of Execution: The Abolition of the Tyburn Ritual' Past and Present, 202 (2009) p. 150.

91. Public Advertiser, 20 July 1770; Westminster Journal and London Political Miscellany, 21 July 1770. 1768-1771 did witness above average numbers of London murder prosecutions.

92. Blackstone, Commentaries, 4, (12th edition, London, 1795) p. 202.

93. P. Smith, Punishment and Culture (Chicago, 2008) p. 50.

94. Public Advertiser, 20 July 1762.

95. Hanway, The Defects, pp. 245-246.

96. The Times, 7 December 1785.

97. Gentleman's Magazine, 46, (1776), p. 449. The author's confidence that the half-hanged offender could be revived may have partly arisen from contemporary reports that this happened. Public Advertiser, 5 November 1774; Hurren, Dissecting, pp. 36-62.

98. Gentleman's Magazine, 25, (1755), p. 295.

99. TNA, SP.44/88/81.

100. Ibid.

101. TNA, SP.44/89/190.

102. St James Chronicle or British Evening Post, 6 and 16 June 1767; Gazetteer and New Daily Advertiser, 10 and 17 June 1767; London Chronicle, 6 June 1767; London Evening Post, 9 June 1767. 
103. London Chronicle, 20 and 23 June 1767; London Evening Post, 25 June 1767; Gazetteer and New Daily Advertiser, 29 June 1767, which reported that the King changed his mind after being told 'there were opportunities enough by the frequent accidents' to try out the styptic.

104. D. Barrington, Observations on the More Ancient Statutes (London, 1769) p. 401 .

105. Eden, Principles, p. 81.

106. Gentleman's Magazine, 24, (1754), pp. 506-507; Gazetteer, 20 July 1764.

107. Middlesex Journal, 16 May 1769.

108. London Magazine, 24, (1755) p. 23.

109. General Evening Post, 24 August 1790.

110. Radzinowicz, A History, 1, p. 217 and R. Houston, Punishing the Dead? Suicide, Lordship and Community in Britain 1750-1830 (Oxford, 2010) p. 257.

111. On profane burial for suicides -Tarlow, Hung, pp. 16-17.

112. Read's Weekly Journal or British Gazetteer, 18 April 1761.

113. St James Chronicle or British Evening Post, 28 May 1768.

114. London Magazine, 35, (1766) p. 406.

115. Gazetteer and New Daily Advertiser, 26 July 1766.

116. Middlesex Journal, 15 June 1776.

117. Morning Post, 16 December 1777.

118. Ward, 'The Criminal Corpse', p. 77; S. Devereaux, 'Inexperienced Humanitarians? William Wilberforce, William Pitt and the Execution Crisis of the 1780s' Law and History Review, 33 (2015) p. 858.

119. The Times, 21 October 1785.

120. Parliamentary Archives, $\mathrm{HL} / \mathrm{PO} / \mathrm{JO} / 10 / 2 / 61$.

121. This was true both in London and in the rest of England and Wales, Devereaux, 'England's', p. 82; D. Hay, 'Hanging and the English Judges' in D. Garland, R. McGowen and M. Meranze (eds.), America's Death Penalty: Between Past and Present (New York, 2011) p. 135.

122. The rising percentage hanged was partly caused by a government crackdown but in 1785 it was also linked to the judges' response to Madan's pamphlet demanding that all pardoning be ended. P. King, Crime, Justice and Discretion in England 1740-1820 (Oxford, 2000) pp. 276-277.

123. The Times, 31 January 1785.

124. Devereaux, 'Inexperienced Humanitarians', pp. 863-865.

125. The Times, 7 February 1785.

126. The Times, 25 and 29 April 1785.

127. Devereaux, 'Inexperienced Humanitarians', p. 867.

128. Ward, 'The Criminal Corpse'; Devereaux, 'Inexperienced Humanitarians'.

129. Ward, 'The Criminal Corpse', pp. 70-79.

130. Devereaux, 'Inexperienced Humanitarians', pp. 842-856. 
131. House of Commons Parliamentary Papers, http://parlpapers.chadwyck. co.uk accessed 8 November 2013, Parliamentary Register (henceforth HOC Papers PR) 20, p. 227.

132. Morning Herald, 17 May 1786; Gentleman's Magazine, 56 (1786) p. 766.

133. General Evening Post, 18 May 1786; Public Advertiser, 17 May 1786; Different reports contain different aspects of the speeches of Wilberforce and Lord Loughborough. I have assumed that if either was recorded anywhere as saying something he actually did so. For Wilberforce's earlier announcement about introducing a bill London Chronicle, 13 May 1786.

134. General Evening Post, 18 May 1786. Other reports say he was less ambitious referring to 'certain heinous crimes', Gentleman's Magazine, 56 (1786) p. 766. Hey's original scheme certainly envisaged the release of all capital convicts' corpses. Ward, 'The Criminal Corpse', p. 71.

135. Parliamentary Archives, $\mathrm{HL} / \mathrm{PO} / \mathrm{JO} / 10 / 2 / 61$. The inclusion of high treason cases 'except where the body ought to be quartered' appears to have been designed to include coining.

136. Ward calculates that the Bill would have produced another seventy cadavers a year nationwide 1776-1785. On average the Murder Act produced just 11.3 cadavers a year in that period. Ward, 'The Criminal Corpse', p. 66.

137. General Evening Post, 18 May 1786.

138. Parliamentary Archives, $\mathrm{HL} / \mathrm{PO} / \mathrm{JO} / 10 / 2 / 61$.

139. Devereaux, 'Inexperienced Humanitarians', pp. 842-856.

140. On Loughborough taking the lead in the Lords and as an opponent of Pitt, B. Montagu, The Opinions of Different Authors on the Punishment of Death (London, 1813), p. 180 and M. McCahill, The House of Lords in the Age of George III (Chichester, 2009) p. 115.

141. Ward, 'The Criminal Corpse', pp. 80-83.

142. 'Of public principle he was wholly destitute, repeatedly going over from the Whigs to the Tories', J. Campbell, The Lives of the Lord Chancellors, 6 (London, 1847) p. 336.

143. HOC Papers, PR, 20, p. 163.

144. London Chronicle, 6 July 1786; Whitehall Evening Post, 6 July 1786.

145. Morning Chronicle, 6 July 1786.

146. Radzinowicz, A History, 1, p. 479.

147. Oracle and Public Advertiser, 12 March 1796.

148. London Chronicle, 24 June 1786.

149. General Evening News, 22 June 1786; S. Devereaux, 'The Abolition of the Burning of Women in England Reconsidered' Crime, History and Societies, 9, (2005) p. 79. For other coverage see Whitehall Evening Post, 22 June 1786, Morning Chronicle and London Advertiser, 22 June 1786.

150. London Chronicle, 24 June 1786. 
151. Devereaux, 'The Abolition', p. 77.

152. Radzinowicz, A History, 1, p. 213; Devereaux, 'The Abolition' p. 75. For the early campaign-The Times, 27 June 1786.

153. R. Campbell, 'Sentence of Death for Burning by Women' Journal of Legal History, 5 (1984) p. 55 suggests that the lack of opposition to the bill was partly due to the backing of many of the judges.

154. Blackstone, Commentaries (12th edition, London, 1795) 4, pp. 203-204; Radzinowicz, A History, 1, pp. 212-213.

155. Devereaux, 'The Abolition', p. 76.

156. Ibid., pp. 73-87 and 94; One in 1786, 1788 and 1789. Only two women were burnt at the stake in London 1759-1785 one for coining, one for the murder of her husband. In 1790 another coiner Sophia Girton was awaiting burning but was saved by the $1790 \mathrm{Act}$, www.oldbaileyonline.org version 6.0., 10 July 2013 t17900424-6.

157. Devereaux, 'The Abolition' pp. 82-93.

158. Ibid., p. 89; Bentham joined the critics suggesting that 'so horrible a punishment as burning alive' should not be used against coiners, J. Bentham, An Introduction to the Principles of Morals and Legislation (London, 1789) p. 177.

159. Ibid., p. 86.

160. Devereaux, 'England's', pp. 82-90. Similar, if less drastic reductions, occurred on various assize circuits, King, Crime, Justice, p. 276; Hay, 'Hanging and the English Judges' pp. 133-134.

161. Devereaux, 'England's', p. 85.

162. Ibid.

163. Oracle and Public Advertiser, 12 March 1796.

164. J. Beattie, Crime and the Courts in England 1660-1800 (Oxford, 1986) p. 631 .

165. Ibid., p. 630.

166. McGowen, 'The Body', p. 655.

167. Ibid., pp. 670-671.

168. The Times, 27 June 1786.

169. Eden, Principles, p. 57; McGowen, 'The Body', p. 670.

170. Ward, 'The Criminal Corpse', p. 67.

171. Devereaux, 'England's', p. 89.

172. The Pocket Magazine, 1 (Issue 4), p. 253.

173. "Beccaria Anglicus", Letters on Capital Punishments (London, 1807) p. 11 .

174. J. Bransby, The Ipswich Magazine for the Year 1799 (Ipswich 1800) pp. 108-109.

175. St James's Chronicle or British Evening Post, 23 January 1796. 
176. Evening Mail, 7 March 1796; Lloyd's Evening Post, 19 December 1796; London Chronicle, 3 January 1797; General Evening Post, 20 November 1800.

177. Mirror of the Times, 26 May 1798.

178. Beattie, Crime, p. 620; M. Ignatieff, A Just Measure of Pain; The Penitentiary in the Industrial Revolution 1750-1850 (London, 1978) pp. 53-54, 96-100.

179. M. Foucault, Discipline and Punish; The Birth of the Prison (Harmondsworth, 1979); P. Spierenburg, The Spectacle of Suffering (Cambridge, 1984); Ignatieff, A Just Measure; R. Ward 'Introduction' in R. Ward (ed.), A Global History of Execution and the Criminal Corpse (Basingstoke, 2015) pp. 18-20.

180. S. Wilf, 'Imagining Justice: Aesthetics and Public Executions in Late Eighteenth-Century England' Yale Journal of Law and the Humanities, 5 (1993) pp. 53-54.

181. Devereaux, 'Recasting the Theatre of Execution'.

182. Wilf, 'Imagining Justice', p. 75

183. H. Fielding, An Enquiry into the Causes of the Late Increase of Robbers (London, 1751) pp. 123-124; Smith, Punishment, p. 50.

184. Anon, Observations on Some Points of law with a System of the Judicial Law of Moses (Edinburgh, 1759) p. 163.

185. The Times, 7 December 1785 and 16 February 1786.

186. Smith, Punishment, p. 51.

187. Gentlemen's Magazine, 56 (1787) p. 1050.

188. V. Gatrell, The Hanging Tree; (Oxford, 1994) pp. 589-591.

189. J. Delaney, 'Bourgeois Bodies-Dead Criminals; England 1750-1850' Diogenes, 36 (1988) p. 80. Ward 'Introduction', pp. 17-18.

190. Ibid., p. 74 .

191. S. Poole, "For the Benefit of Example": Crime-Scene Executions in England, 1720-1830' in Ward (ed.), A Global History, p. 76.

192. Ibid., pp. 76-83.

193. Ibid., p. 96.

194. Devereaux, 'England's', pp. 82-91.

195. Hay, 'Hanging and the English Judges' p. 134; There were slight differences between circuits, King, Crime, Justice, p. 275.

196. R. McGowen, 'Managing the Gallows: The Bank of England and the Death Penalty 1797-1821' Law and History Review, 25 (2007) pp. 241282; Hay, 'Hanging and the English Judges', p. 135.

197. Gatrell, The Hanging Tree, p. 9.

198. Devereaux, 'England's', pp. 90-91.

199. 23 murderers were gibbeted 1792-1801. 
200. Radzinowicz, A History, 1, pp. 506-509, 517, 522, 539. Eldon certainly believed that it was not 'the severity of the law being put into execution to the fullest extent' that mattered 'so much as the imaginary terror of it', and he may therefore have decided that the best way to preserve the capital code was to keep almost all of it on the statute books but make more limited use of it in practice. As Radzinowicz noted, both Eldon and Ellenborough agreed that crime was best prevented by appointing capital punishment for many offences, but then executing it in a few cases only (p. 506). Since Hay has shown that Ellenborough was much less punitive than most other judges his influence cannot be ruled out, despite his harsh approach to political trials and penal reform, 'Hanging and the English Judges' pp. 139-150.

201. On the judges high level of general agreement see Radzinowicz, A History, 1 , pp. 508-509.

202. Ibid., pp. 497-503; Devereaux, 'England's', p. 91; Poole, 'For the Benefit', p. 76.

203. Radzinowicz, A History, 1, pp. 497-525.

204. This was passed after much amendment as 54 Geo.3, c.145 (1814).

J. Chitty, A Practical Treatise on the Criminal Law (London, 1816) p. 702 .

205. B. Montagu, The Debate upon Sir Samuel Romilly's Bill on the Punishment for High Treason (London, 1813) pp. 16 and 25. On the mitigation of aggravated treason execution rituals in practice see Blackstone, Commentaries, 4 (a new edition with analysis by J. Archibald, London, 1811) p. 376.

206. Ibid., p. 3 and 15.

207. Ibid., p. 41.

208. R. McGowen, 'The Image of Justice and Reform of the Criminal Law in Early Nineteenth-Century England' Buffalo Law Review, 37 (1983) pp. 99-100.

209. Montagu, The Debate, p. 38.

210. Ibid., p. vii and 7.

211. Gatrell, The Hanging Tree, pp. 298-321; For more detail on these treason executions see Tarlow, Hung, pp. 13-16.

212. Gatrell, The Hanging Tree, p. 321.

213. Hansard, The Parliamentary Debates, 28 col. 187.

214. Ibid.

215. Montagu, The Debate, p. 25; Clement's Official Edition of the Police Report (London, 1816), pp. 212-213.

216. H. Woolrych, The History and Results of the Present Capital Punishments in England (London, 1832) p. 104; Gatrell, The Hanging Tree, p. 268; 
217. TNA, HO 44/14/87 letter from Mr Dykes to Robert Peel; Gatrell, The Hanging Tree, p. 268.

218. TNA, HO 44/14/87.

219. Gatrell, The Hanging Tree, p. 268.

220. Radzinowicz, A History, 1, p. 219; London Metropolitan Archive, Print Collection, Pr.P2/BLA.

221. Hansard, The Parliamentary Debates, 28 col. 187.

222. Hurren, Dissecting.

223. Lancashire Gazette and General Advertiser, 23 August 1828; Jackson's Oxford Journal, 23 May 1828.

224. Poole, 'For the Benefit', p. 72.

225. Bury and Norwich Post, 3 February 1802; G. Durston, Fields, Fens and Felonies; Crime and Justice in an Eighteenth-Century English Region (forthcoming) p. 278-279 quoting Ipswich Journal, 3 April 1813.

226. E. Frizelle, The Life and Times of the Royal Infirmary at Leicester (Leicester, 1988) pp. 261-264; Hurren, Dissecting, pp. 219-239.

227. Ipswich Journal, 22 November 1817.

228. J. Disney, Outlines of a Penal Code on the Basis of the Laws of England (London, 1826) pp. 2-12, 23, 61.

229. PP., 1826-7, (534) vi, p. 61.

230. Gentlemen's Magazine, 84 (1814) p. 620; 91 (1821) p. 482.

231. Richardson, Death. For the growth of a massive trade in pauper cadavers E. Hurren, Dying for Victorian Medicine: English Anatomy and its Trade in the Dead Poor 1832-1929 (Basingstoke, 2011).

232. TNA HO44/15/83-83a.

233. Lancet, 11, p. 324-325.

234. Richardson, Death.

235. Hansard, The Parliamentary Debates, 2nd Series, 18 col. 1137.

236. 9 Geo.4, c.15; Radzinowicz, A History, l, p. 586.

237. Hansard, The Parliamentary Debates, 2nd Series, 18 col. 1358.

238. Ibid.

239. Morning Chronicle, 16 April 1828.

240. Hansard, The Parliamentary Debates, 2nd Series, 18 col. 1443-45.

241. Morning Chronicle, 16 April 1828.

242. Hansard, The Parliamentary Debates, 2nd Series, 18 col. 1443-44.

243. Morning Chronicle, 16 April 1828.

244. Hansard, The Parliamentary Debates, 2nd Series, 18 col. 1444.

245. Richardson, Death, p. 107; Manchester Courier and Lancashire General Advertiser, 15 March 1828.

246. Hansard, The Parliamentary Debates, 2nd Series, 18 col. 1611-23.

247. Hansard, The Parliamentary Debates, 2nd Series, 18 col. 1613-14.

248. Ibid. 
249. Richardson, Death, pp. 108-110.

250. PP. 1829 (568) vii, p. 19 and 38. Witnesses-pp. 19, 33-34, 41, 42, 43, $47,55,74,76,81,83,86,105,116$ and for slightly more guarded endorsements pp. $24,31,77,100$

251. Ibid., p. 95.

252. Ibid., p. 11.

253. Ibid., p. 11-12.

254. Richardson, Death, pp. 113-114.

255. Mirror of Parliament (1829), pp, 1672-1673.

256. Ibid., p. 1675.

257. Ibid., p. 1673.

258. Hansard, The Parliamentary Debates, 2nd Series, 21, col. 1747-9, and 3rd series, 9 col. 300-301.

259. Ibid., pp. 1748-1749.

260. Ibid., pp. 1831-1835.

261. Hansard, The Parliamentary Debates, 3rd Series, 9, col 252-316.

262. Richardson, Death, pp. 143, 199-215; B. Bailey, The Resurrection Men; A History of the Trade in Corpses (London, 1991), pp. 142-149.

263. HOC, PP, 1831-1832 (35)2 Will.IV.-Sess 1831-2 A Bill for Regulating Schools of Anatomy.

264. Medicus, An Exposure of the Present System for Obtaining Bodies for Dissection and a More Consistent Plan Suggested (London, 1829) p. 11.

265. Richardson, Death, p. 144; Hurren, Dissecting, pp. 43-60 argues that (p. 55) 'the surgeons were duty bound by the legislation to keep secret the conundrum of medical death'. By 1832 surgeons were beginning to go public on the fact that bodies were given over to them for 'the completion of the penalty' (p. 38).

266. J. Somerville, A Letter Addressed to the Lord Chancellor on the Study of Anatomy (London, 1832) p. 8; Proceedings of the National Political Union Respecting the Legislative Interference in the Study of Anatomy (London, $1832)$ p. 18.

267. Quarterly Review, 42 (1830) p. 15.

268. J. Riadore, Suggestions on the Best Means of Supplying Anatomical Schools (London, 1831) pp. 3-4.

269. G. Guthrie, A Letter to the ... Home Department, Containing Remarks on the Report of the Select Committee on Anatomy (London, 1829) pp. 11-12. $\mathrm{He}$ also suggested other categories including the unclaimed poor.

270. The Moral Reformer, l (1831) p. 13.

271. HC/CL/JO/6/167 pp. 152 and 66.

272. Hansard, The Parliamentary Debates, 3rd Series, 9, col. 701-3, 838-842.

273. Ibid., 13, col. 824-8 and Times, 20 June 1832.

274. Ibid., 13, col. 825-8. 
275. Ibid., 10, col. 838-9.

276. Ibid., 10, col. 836-8.

277. Ibid., 9, col. 558-585 and 10, col. 833-5.

278. Ibid., 9, col. 304-7; see also Cresset Pelham M.P.-9, col. 558-585, Rigby Wason M.P.- 10, col. 834-6.

279. Ibid., 12, col 667-9.

280. The Times, 20 June 1832.

281. Hansard, The Parliamentary Debates, 3rd Series, 13, col. 827-9; Morning Chronicle, 20 June 1832.

282. Morning Chronicle, July 201832.

283. Hansard, The Parliamentary Debates, 3rd Series, 14, col. 531-6.

284. Ibid.

285. Ibid.

286. Freeman's Journal, 24 January 1832; Hansard, The Parliamentary Debates, 3rd Series, 9, col. 827-8.

287. Anon, The Punishment of Death: A Selection of Articles from the Morning Herald (London, 1837) p. 11.

288. On Wynford in 1827 (as Judge Best) Gatrell, The Hanging Tree, p. 268.

289. Anon, The Punishment of Death, p. 12.

290. Morning Chronicle, 4 August 1832; Hull Packet and Humber Mercury, 7 August 1832; Belfast New-Letter, 10 August 1832 best conveys the judges tentative understanding of the new law.

291. Morning Chronicle, 10 August 1832.

292. Ibid., and Newcastle Currant, 4 August 1832.

293. Morning Chronicle, 10 August 1832.

294. Gatrell, The Hanging Tree, p. 269; Radzinowicz, A History, 1, p. 220. Jobling's corpse hung on the banks of the Tyne attracted great crowds especially at high tide-Anon, The Punishment of Death, p. 9.

295. Bristol Mercury, 25 August 1832.

296. Royal Cornwall Gazette, 25 August 1832.

297. Anon, The Punishment of Death, p. 144.

298. Quoted in Ibid., pp. 144-145.

299. Anon, The Punishment of Death, p. 7.

300. Bristol Mercury, 25 August 1832.

301. Anon, The Punishment of Death, pp. 8-11.

302. Leicester and Nottingham Journal, 18 August 1832.

303. GIJHC, 89, pp. 195, 291, 355, 367, 394, 414. The bill was $1834(221) 4$ Will.IV -Sess1834;

304. Hansard, The Parliamentary Debates, 3rd Series, 22, col. 126-190. Radzinowicz, A History, 1, p. 601.

305. GIJHL, 66, pp. 650, 780,793; Hansard, The Parliamentary Debates, 3rd Series, 22, col. 1213-1222. 
306. GIJHL, 66, pp. 800, and 805 .

307. Radzinowicz, A History, 1, pp. 601-605.

308. Hansard, The Parliamentary Debates, 3rd Series, 22, col. 674-733; and 25, col. 91-126.

309. Ibid., 23, 894-950.

310. Alexipharmacus, A General Exposition of the State of the Medical Profession (London, 1829) p. 13; In the Examiner, 1 July 1832 Brougham argued that while 'the taking away of human life was justly punishable by death', he did not approve of crowding under one head a number of offences that ought not to be so punished.

311. Hansard, The Parliamentary Debates, 2nd Series, 18 col. 1613-14.

312. Radzinowicz, A History, 1, pp. 601-605.

313. Devereaux, 'Inexperienced Humanitarians', pp. 857-858 argues cogently that the Murder Act actually reduced the number of cadavers the London surgeons received.

Open Access This chapter is licensed under the terms of the Creative Commons Attribution 4.0 International License (http://creativecommons.org/licenses/by/ $4.0 /$ ), which permits use, sharing, adaptation, distribution and reproduction in any medium or format, as long as you give appropriate credit to the original author(s) and the source, provide a link to the Creative Commons license and indicate if changes were made.

The images or other third party material in this chapter are included in the chapter's Creative Commons license, unless indicated otherwise in a credit line to the material. If material is not included in the chapter's Creative Commons license and your intended use is not permitted by statutory regulation or exceeds the permitted use, you will need to obtain permission directly from the copyright holder.

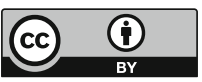

